Muzeum Ogrodu Botanicznego, Instytut Botaniki, Wydział Biologii, Uniwersytet Jagielloński

\title{
Muzeum Ogrodu Botanicznego Uniwersytetu Jagiellońskiego w Krakowie - przeszłość i teraźniejszość
}

\author{
ABSTRACT \\ Museum of the Botanic Garden, Jagiellonian University in Cracow - past \\ and present
}

The Museum of the Botanic Garden, the Jagiellonian University in Cracow (the oldest Polish botanical garden founded in 1783) holds materials illustrating scientific and didactic activity of the Cracow botanical centre. In 1983, exhibition was arranged in the Garden, on the first floor of the Śniadecki Collegium. The botanical collection includes dendrological and carpological (fruits and seeds) specimens, as well as plant organs stored in liquid, gathered in the Botanic Garden or during field research of botanists in Africa, America, Asia, Europe, and the polar regions, mostly in the 19-21th centuries. Among the largest, there is the collection of Marian Raciborski (1863-1917) (Java, Indonesia, 1896-1900). Additionally, the Museum holds various materials about the history of botany. The subject of the exhibition is the history of the Cracow Botanic Garden and various tropical specimens from Africa, and Asia, as well as plants and lichens from the polar regions. Temporary exhibitions are mostly devoted to the plant motives in art. The research program focuses on the history of botany, ethnobotany, as well as the question of the relations between nature, science, and culture. Throughout the year the Museum is open to students, while normal visitors may access the Museum in time the Botanic Garden is open i.e. from April to October.

Keywords: Africa, Botanic Garden, botanical museum, carpological specimens, Cracow, dendrological specimens, Dyakowska, ethnobotany, history of botany, Jagiellonian University, Java, 'Kilimanjaro 75', Kornaś, Medwecka-Kornaś, nature - science - culture relations, Olech, Raciborski, Rostafiński, Szafer, Śniadecki, Warszewicz 
Słowa kluczowe: Afryka, dendrologiczne okazy, Dyakowska, etnobotanika, historia botaniki, Jawa, Kraków, muzeum botaniczne, karpologiczne okazy, „Kilimandżaro 75”, Kornaś, Medwecka-Kornaś, Ogród Botaniczny, Olech, Raciborski, relacje przyroda - nauka - kultura, Rostafiński, Szafer, Śniadecki, Uniwersytet Jagielloński, Warszewicz

Ogrody botaniczne - „ogrody wiedzy”, „żywe muzea flory świata” - służą badaniom naukowym i przekazywaniu wiedzy o roślinach. W dzisiejszych czasach ich ważną misją jest ochrona gatunków ginących i zagrożonych w naturze ${ }^{1}$, edukacja przyrodnicza społeczeństwa, a także popularyzacja całościowego, interdyscyplinarnego spojrzenia na naturę i człowieka. Należą do najstarszych zakładów naukowych. Za pierwszy uważa się ogród botaniczny istniejący przy sławnej szkole filozoficznej Liceum Arystotelesa w Atenach. Uczeń Arystotelesa, Teofrast z Erezu (ok. 370-287 roku p.n.e.), określany mianem ojca botaniki, obserwował rośliny i nauczał o ich budowie, środowisku życia i użytkowaniu przez człowieka. Nowożytne ogrody zaczęto tworzyć w uniwersytetach europejskich w okresie renesansu, wraz z postępującą eksploracją zamorskich krajów i ich flory. Obecnie za najstarszy na świecie uważany jest Ogród Botaniczny Uniwersytetu w Padwie, założony w 1545 roku². Przy niektórych starych ogrodach istnieją wydzielone działy muzealne, zawierające spreparowane okazy roślin, wyroby rzemiosła, obrazy natury, a także różnego typu archiwalia i inne obiekty. Są to zatem muzea przyrody, a zarazem nauki i sztuki. Do najsławniejszych należą m.in. muzea ogrodów botanicznych w Londynie (Royal Botanic Gardens, Kew - Economic Botany Collection) i Berlinie (Botanischer Garten und Botanisches Museum Berlin-Dahlem). Posiadają one ogromne zbiory przechowywane w okazałych budynkach. Ogrodowe muzea są dopełnieniem żywych zbiorów pod gołym niebem, gdzie historia roślin splata się z losami ludzi, a stare drzewa, krzewy i rośliny zielne są pomnikami przeszłości (zob. niżej: „Ogród Botaniczny Uniwersytetu Jagiellońskiego jako muzeum”).

Najstarszy w Polsce Ogród Botaniczny Uniwersytetu Jagiellońskiego w Krakowie (il. I) założony w 1783 roku ma osobny dział - Muzeum Ogrodu Botanicznego. Jest ono usytuowane na parterze zabytkowego gmachu Collegium Śniadeckiego UJ stojącego przy wejściu od ul. Kopernika 27. W XVII wieku był to podmiejski pałacyk, później kolegium jezuickie, a po przebudowie w latach 1787-1791 Obserwatorium Astronomiczne urządzone w 1792 roku przez Jana Śniadeckiego (1756-1830), matematyka, geografa i astronoma. Po wyprowadzeniu się astronomów budynek przemianowano w 1963 roku na Collegium Śniadeckiego UJ. Muzeum zostało zaaranżowane na ok. XVII-wiecznym parterze, użytkowanym przez wiele lat jako mieszkanie służbowe dyrektorów Ogrodu. Posiada powierzchnię ok. $212 \mathrm{~m}^{2}$. Składa się z dziewięciu pokojów,

${ }^{1}$ Botanic gardens. A living history, red. N.K. Monem, London 2007; S. Oldfield, Botanic garden Modern-day arks, London, Cape Town, Sydney, Auckland 2010.

2 A.G. Morton, History of botanical science. An account of the development of botany from ancient times to the present day, London, New York, Toronto, Sydney, San Francisco 1981; K. Mägdefrau, Historia botaniki. Życie i dokonania wielkich badaczy, przeł. M. Mularczyk, Wrocław 2004; A. Zemanek, Historia botaniki [History of botany] [w:] Dzieje nauki. Nauki ściste i przyrodnicze [History of science. Exact sciences and natural sciences], red. M. Siwiec, Warszawa, Bielsko-Biała 2011, s. 390-455. 


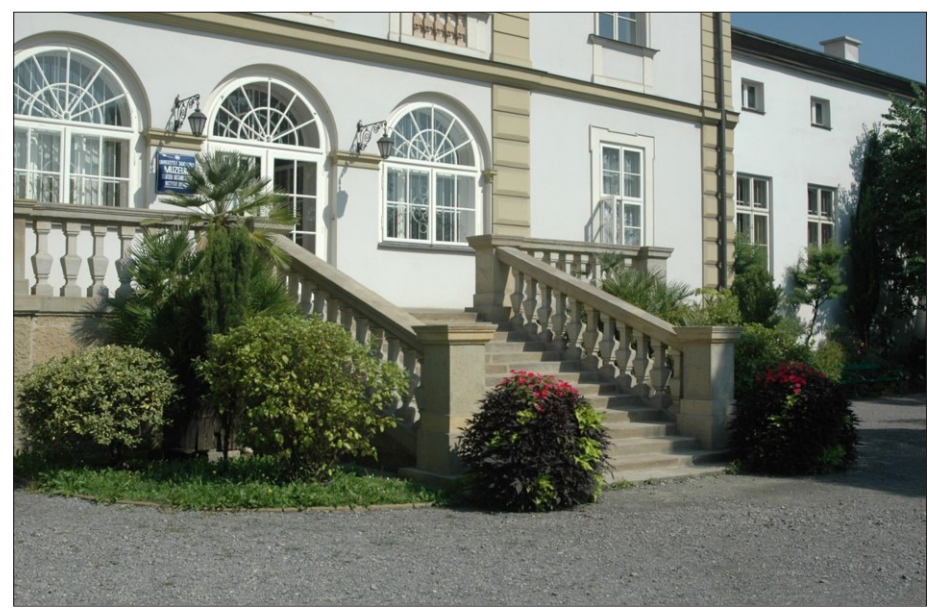

Il. 1. Wejście do Muzeum Ogrodu Botanicznego UJ. Fot. A. Mróz. Ze zbiorów Muzeum Ogrodu Botanicznego UJ

w tym pięciu pełniących funkcję magazynów (dwa spośród nich na II piętrze), a zarazem pracowni (ok. $102 \mathrm{~m}^{2}$ ) oraz czterech sal ekspozycyjnych (ok. $110 \mathrm{~m}^{2}$ ), z wyjściem na taras prowadzący do Ogrodu Botanicznego (il. 1). Muzeum, dostępne dla publiczności, prowadzi działalność dokumentacyjną i naukową, a także przyczynia się do popularyzacji wiedzy o roślinach oraz dawnych botanikach, pozwala też na podziwianie piękna przyrody utrwalanego przez artystów we współczesnych dziełach sztuki.

Celem artykułu jest syntetyczny opis tej mało znanej krakowskiej jednostki muzealnej, a zwłaszcza przedstawienie historii i obecnie funkcjonującej ekspozycji. Różne aspekty Muzeum oraz studia szczegółowe nad wybranymi kolekcjami opublikowano w pracach cytowanych poniżej ${ }^{3}$, przy czym najnowsze dzieje odtworzone są na podstawie muzealnych materiałów archiwalnych (ponad 30 jednostek) oraz prowadzonych przez autorkę notatek.

${ }^{3}$ A. Piekiełko-Zemanek, Zbiory muzealne Ogrodu Botanicznego Uniwersytetu Jagiellońskiego w Krakowie. Museum assemblage of Botanical Garden of the Jagiellonian University in Kraków, „Wiadomości Botaniczne” 1985, t. 29, z. 1, s. 59-68; P. Köhler, A. Zemanek, Dziesięciolecie otwarcia Muzeum Ogrodu Botanicznego Uniwersytetu Jagiellońskiego w Krakowie (1983-1993). Ten years of the Museum of the Jagiellonian University Botanic Garden, Cracow, Poland (1983-1993), „Wiadomości Botaniczne” 1994, vol. 38, nr 3/4, s. 170-174; A. Zemanek, Muzeum Ogrodu Botanicznego UJ [Museum of the Botanic Garden JU], „Alma Mater” 2013, nr specjalny, wrzesien, nr 158, s. 111-114; A. Zemanek, Muzeum Ogrodu Botanicznego Uniwersytetu Jagiellońskiego [Museum of the Botanic Garden, Jagiellonian University] [w:] Muzea uczelniane Katalog [Association of University Museums Catalogue], red. H. Kowalski, M. Grassmann, M. Bukowski, J. Ślaga, M. Piszczatowska, M. Przybyszewska (red. prowadzący), Warszawa 2017, s. 126-131; A. Zemanek, P. Klepacki, Muzeum Ogrodu Botanicznego Uniwersytetu Jagiellońskiego w Krakowie [Museum of the Botanic Garden, Jagiellonian University in Cracow] [w:] Muzealnictwo przyrodnicze w Polsce [Museology of natural history in Poland], red. D.J. Gwiazdowicz, Gołuchów 2017, s. 105-113. 


\section{Historia}

Muzeum związane jest z długoletnią działalnością Ogrodu Botanicznego Uniwersytetu Jagiellońskiego oraz krakowskiego ośrodka naukowego, zwłaszcza Instytutu Botanicznego UJ utworzonego w 1913 roku (od 1970 roku Instytutu Botaniki) ${ }^{4}$. Zbiory zaczęto gromadzić pod koniec XVIII wieku, a w późniejszych latach systematycznie je wzbogacano ${ }^{5}$. Początkowo były częścią Gabinetu Historii Naturalnej, który wraz z Ogrodem Botanicznym był zakładem pomocniczym Katedry Chemii i Historii Naturalnej. Katedra utworzona w 1780 roku z inicjatywy Komisji Edukacji Narodowej obejmowała całość ówczesnych nauk o przyrodzie: botanikę, zoologię i mineralogię, a także chemię. Gabinet Historii Naturalnej, w którym gromadzono okazy botaniczne, zoologiczne i geologiczne, mieścił się w Kolegium Fizycznym (obecnym Kolegium H. Kołłątaja) przy ul. św. Anny 6.

Prof. Jan Jaśkiewicz (1749-1809), pierwszy dyrektor Ogrodu w latach 1783-1787, zgromadził niewielki zbiór dendrologiczny krajowych gatunków drzew, z którego pozostało kilka okazów ${ }^{6}$. Przechowywano również dwa XVIII-wieczne zielniki przywiezione z południowej Europy przez profesorów Akademii Krakowskiej Andrzeja Badurskiego i prawdopodobnie Antoniego Camelina. Obydwa zachowały się w Herbarium Instytutu Botaniki UJ jako jedne z najstarszych w Polsce ${ }^{7}$. Dużą kolekcję botaniczną liczącą 237 okazów uzyskano zapisem testamentowym z 1815 roku od dziekana kapituły krakowskiej, a zarazem kolekcjonera, księdza Michała Sołtyka. Do dziś przetrwał jeden okaz przeciętego owocu palmy kokosowej, czyli tzw. orzecha kokosowego (dolna część), i cztery naczynia wykonane z wewnętrznej części orzecha. Spośród nich puchar rzeźbiony w barokowe ornamenty roślinne, z inicjałem SM i datą 1687, jest najstarszym okazem muzealnym. W czasach działalności prof. Alojzego Estreichera (1786-1852), dyrektora w okresie 1809-1843, zbiory botaniczne wydzielono z Muzeum Historii Naturalnej. Zostały przeniesione najpierw do Obserwatorium, a później do wschodniego pawilonu Ogrodu stojącego po lewej stronie od bramy wejściowej na dziedziniec. Pawilon ten, przebudowany z dawnych stajni dworskich w 1833 roku, mieści od 1852 roku salę wykładową na piętrze i służy do dziś celom dydaktycznym (przy czym w różnych okresach zmieniano przeznaczenie znajdujących się tu pomieszczeń). Niestety, zielniki złożone na niewykończonym pierwszym piętrze, zgromadzone przez Estreichera i wcześniej - przez ogrodnika Józefa Polaczka - uległy zniszczeniu. Z kolekcji innych okazów

${ }^{4}$ A. Zemanek, Sto lat Instytutu Botaniki Uniwersytetu Jagiellońskiego (1913-2013). (Sum.: 100 years of Institute of Botany of the Jagiellonian University), Kraków 2013.

5 J. Świecimski, A. Zemanek, Muzeum Ogrodu Botanicznego Instytutu Botaniki Uniwersytetu Jagiellońskiego w Krakowie. (Sum.: Botanical Garden Museum in the Institute of Botany, the Jagiellonian University in Cracow), ,Zeszyty Naukowe UJ. Opuscula Musealia” 1992, z. 6, s. 7-19.

${ }^{6}$ P. Köhler, Najstarsze zbiory Muzeum Ogrodu Botanicznego Uniwersytetu Jagiellońskiego. The oldest collections in the Museum of the Jagiellonian University Botanic Garden, „Wiadomości Botaniczne" 1991, vol. 35, nr 1, s. 74-78.

${ }^{7}$ A. Piekiełko, Dwa osiemnastowieczne zielniki ze zbiorów Instytutu Botaniki Uniwersytetu Jagiellońskiego. (Sum.: Two 18-th century herbaria from the collection of the Institute of Botany of the Jagiellonian University), Wrocław, Warszawa, Kraków, Gdańsk 1981. 
liczącej 45 sztuk zachowały się tylko trzy: „korzeń postaci ręki”, „szyszka cedrowa” i ,szyszka sosny włoskiej”.

W czasach sprawowania kierownictwa (1843-1878) przez prof. Ignacego Rafała Czerwiakowskiego (1808-1882), profesora utworzonej w 1847 roku Katedry Botaniki, powiększyły się głównie zbiory zielnikowe, podczas gdy z pozostałych przetrwało tylko 37 okazów dendrologicznych ${ }^{8}$. Prof. Józef Rostafiński (1850-1928), dyrektor w latach 1878-1901 (formalnie do 1910), oddzielił zielnik liczący kilkadziesiąt tysięcy arkuszy od pozostałych zbiorów i urządził w dużej sali na parterze Obserwatorium wystawę wybranych okazów muzealnych, która przetrwała do pierwszej wojny światowej. W 1918 roku zbiory dendrologiczne (drewna) i karpologiczne czyli owoce i nasiona liczyły 684 pozycje.

Do rozwoju Muzeum przyczynił się prof. Marian Raciborski (1863-1917), dyrektor w latach 1912-1917, założyciel Instytutu Botanicznego w 1913 roku. Raciborski, który zasłynął pionierskimi badaniami prowadzonymi na Jawie w Indonezji, gdzie przebywał w latach 1896-1900, przywiózł bogate zbiory botaniczne, które były po części dokumentacją badań, a częściowo zostały zebrane dla celów dydaktycznych i popularyzatorskich. Umieścił je w zachodnim pawilonie Ogrodu, istniejącym w obecnym kształcie od 1829 roku, z mieszkaniami ogrodników na parterze i pracownią na piętrze, gdzie rozpoczął prace nad uporządkowaniem zbiorów i ich konserwacją. Po śmierci Raciborskiego spadkobierca Adam Stobiecki przekazał w dniu 4 maja 1920 roku jego spuściznę Uniwersytetowi Jagiellońskiemu. Duża jej część to były zielniki, a poza tym zbiory dendrologiczne, karpologiczne oraz okazy mokre przechowywane w słojach i próbówkach, zakonserwowane w spirytusie (łącznie ok. 1500 okazów). W spuściźnie uczonego znalazły się też fotografie (ponad 100 sztuk z Jawy), obrazy, które kiedyś zdobiły jego gabinet, a także meble - według tradycji: biurko, wyścielane krzesło i stylowa kanapa - trafiły one do pracowni Muzeum Ogrodu Botanicznego dopiero w drugiej połowie XX wieku.

Następca Raciborskiego prof. Władysław Szafer (1886-1970), jeden z najsławniejszych polskich botaników, dyrektor Ogrodu w latach 1917-1941 oraz 1945-1960, wzbogacił znacznie zbiory krajowe, zwłaszcza dendrologiczne. Z braku odpowiedniego pomieszczenia przechowywał okazy muzealne w służbowym mieszkaniu na parterze Obserwatorium, a od 1928 roku na pierwszym piętrze Instytutu Botaniki przy ul. Lubicz 46. W czasie drugiej wojny światowej okupanci zwolnili W. Szafera.

Kierownictwo nowo utworzonych Zakładów Botanicznych Generalnego Gubernatorstwa (Botanische Anstalten des Generalgouvernements) sprawował w latach 1941-1944 dr Wilhelm Herter (1884-1958). Zbiory przenoszone w różne miejsca zostały częściowo zniszczone, większość jednak przetrwała dzięki staraniom polskiego personelu zatrudnionego w Ogrodzie. Po wojnie materiały używane w czasie zajęć ze studentami umieszczone zostały w pawilonie dydaktycznym. Okazy ułożono w starych dwupiętrowych szafach z zabudowanymi podstawami, na których stały oszklone witryny z półkami na eksponaty. Tablice z rysunkami i obrazami przedstawiającymi gatunki, struktury anatomiczne i schematy, pochodzące w dużej mierze z XIX w., przechowywano w specjalnej, masywnej szafie mającej podstawę z szufladami. Szafa ta stała w pokoju przygotowawczym obok sali wykładowej na piętrze, gdzie przez długie lata mieszkali asystenci. Zbiorami opiekował się laborant Piotr Łagowski (1918-2012). Po rozpoczęciu

\footnotetext{
${ }^{8}$ P. Köhler, Najstarsze zbiory..., s. 77.
} 
pracy musiał złożyć uroczystą przysięgę profesorowi Szaferowi, że nigdy nie dopuści do zniszczenia zbiorów (wywiązał się z niej znakomicie, ponieważ wiele lat później ocalił od wyrzucenia najstarsze okazy muzealne). W późniejszych latach pracowały tu dr Anna Drozdowicz i mgr Monika Rdest-Kogut. W latach powojennych na parterze Obserwatorium Astronomicznego, w przybudówce $\mathrm{z}$ witrażami, urządzone zostało Muzeum Dendrologiczne przy Ogrodzie Botanicznym w Krakowie, którego kierownikiem był doc. dr Karol Ermich (1904-1976) - pracownik Instytutu Botanicznego UJ oraz Zakładu (później Instytutu) Botaniki PAN. Muzeum składało się z siedmiu szaf ustawionych pod ścianami oraz stojącej na środku gabloty. Okazy w szafach, m.in. przekroje pni, ułożone były na półkach. W jednej z szaf przedstawiono przenoszenie nasion przez prądy morskie, w innej znajdowały się suche owoce i szyszki. Franciszek Pawęski, który krótko opisał wystawę , ocenia ją jako przestarzałą (ciemne wnętrza szaf, słabo widoczne okazy przysłonięte szprosami, mało czytelne podpisy). Autorka tego artykułu pamięta, że w 1976 roku w dużej, sześciokątnej sali stały niszczejące szafy z przekrojami dendrologicznymi i okazami mokrymi, oraz zaaranżowana była wystawa pni palm, dużych owoców i nasion ułożonych na stopniach obitych szarym płótnem. W 2. połowie XX wieku zielnik przeniesiono do Instytutu Botaniki UJ, a później do osobnego pawilonu Herbarium Instytutu Botaniki UJ urządzonego w 2001 roku, w kompleksie zabudowań przy ul. Kopernika 31. Profesor Szafer zmarł w 1970 roku, a kilka lat później członkowie jego rodziny opuścili mieszkanie służbowe na parterze dawnego Obserwatorium, przemianowanego wcześniej na Collegium Śniadeckiego.

W 1978 roku, dzięki staraniom dyrektora Ogrodu prof. dr. hab. Kazimierza Szczepanka, zwolnione pokoje przeznaczono na cele muzealne. Dostojny gmach Collegium był wówczas w bardzo złym stanie technicznym. W 1979 roku po koniecznym, jednakże powierzchownym remoncie i urządzeniu magazynu zabezpieczono zbiory oraz rozpoczęto prace nad ich dokumentacją. Przeprowadzono również renowację bardzo zniszczonych, stoczonych przez korniki XIX-wiecznych szaf i dwupoziomowej sześciokątnej gabloty. W dniu 26 maja 1983 roku, w czasie uroczystości jubileuszu 200-lecia Ogrodu Botanicznego UJ, otwarto stałą ekspozycję (il. 2, 3). Prace nad jej urządzeniem trwały w latach 1980-1983. Autorką scenariusza była dr Alicja Zemanek, projektu plastycznego - doc. dr hab. Jerzy Świecimski (1927-2012) ${ }^{10}$ - zoolog, muzeolog i artysta malarz, zatrudniony w Muzeum Przyrodniczym Zakładu Zoologii Systematycznej i Doświadczalnej PAN. Koncepcja scenariusza miała na celu prezentację historii Ogrodu Botanicznego i botaniki w ośrodku krakowskim oraz zagadnień geografii roślin i ekologii, wiążących się z eksponatami, które pochodziły głównie z obszarów tropikalnych. Oryginalny projekt plastyczny J. Świecimskiego, „wpisujący” przyrodniczą ekspozycję w historyczne wnętrza, sprawił, że powstało niezwykłe miejsce, pozwalające na refleksję nad

9 F. Pawęski, Muzealnictwo botaniczne, praca doktorska, promotor: prof. dr Jakub Mowszowicz, b. r. Egzemplarz w Bibliotece Instytutu Botaniki im. W. Szafera PAN, sygn. III 3155. Zawiera ,Szkic Muzeum Dendrologicznego przy Ogrodzie Botanicznym w Krakowie" [k. 54, k. 55, planik k. 6]. Autor błędnie podaje, że Muzeum należy do Instytutu Botanicznego PAN (w rzeczywistości Muzeum wraz z Ogrodem znajdowało się w obrębie Instytutu Botanicznego UJ).

10 E. Warchałowska-Śliwa, Jerzy Świecimski (1927-2012), prof. dr hab. [w:] Ćwierćwiecze Instytutu Systematyki i Ewolucji Zwierzą Polskiej Akademii Nauk w Krakowie. 150 lat tradycji badawczych i muzealnych, red. E. Warchałowska-Śliwa, Kraków 2014, s. 99. 


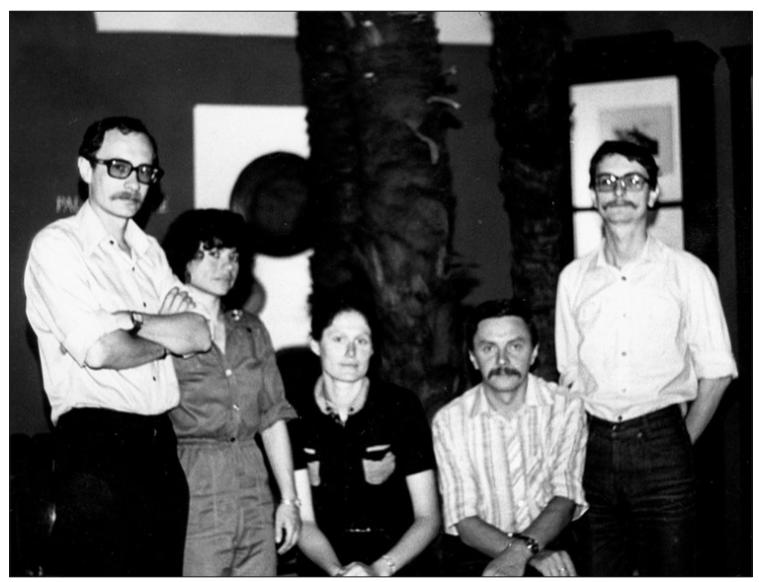

II. 2. Urządzanie stałej ekspozycji muzealnej w 1983 roku. Od lewej: Bogdan Zemanek, Alicja Zemanek, Elżbieta Nowotarska, Józef Wróbel, Józef Mitka. Ze zbiorów Muzeum Ogrodu Botanicznego UJ

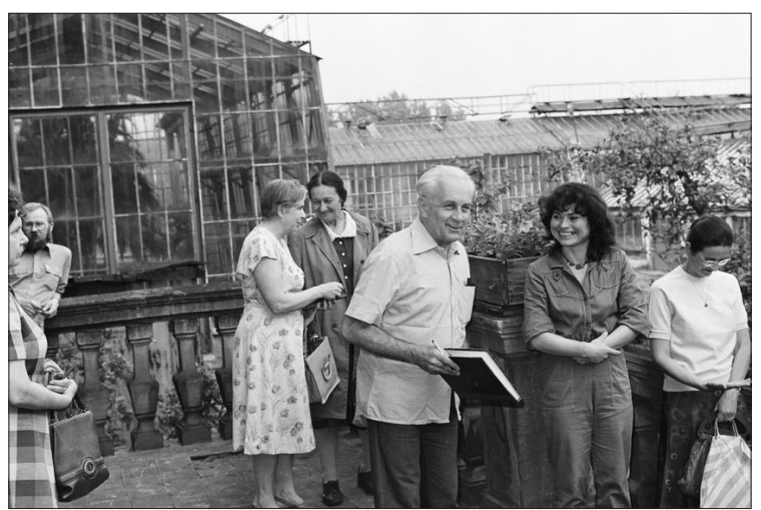

II. 3. Czwartek botaniczny, czyli zebranie członków Krakowskiego Oddziału Polskiego Towarzystwa Botanicznego - dyskusja przed wejściem do nowo urządzonego Muzeum. Od prawej: Romana Izmaiłow, Alicja Zemanek, Jan Kornaś, Maria Reymanówna, Anna Medwecka-Kornaś, Jan Wójcicki, Barbara Gumińska. Fot. J. Wróbel, maj 1983. Ze zbiorów Muzeum Ogrodu Botanicznego UJ

przeszłością nauki i egzotycznymi roślinami, na tle pięknie wyeksponowanej dawnej architektury ${ }^{11}$. Muzeum obejmowało wtedy sześć pomieszczeń ekspozycyjnych (w tym małą przybudówkę i wąski korytarz).

Niestety, gmach Collegium Śniadeckiego stawał się coraz bardziej zrujnowany, z powodu braku funduszy na remont - zawilgocenie ścian w korytarzu i pojawienie się szczelin w ścianach przybudówki sprawiły, że trzeba było je wyłączyć z ekspozycji. Stylowe, głównie XIX-wieczne piece opalano węglem. W 1988 roku zostały w nich

11 J. Świecimski, A. Zemanek, Muzeum Ogrodu Botanicznego Instytutu Botaniki Uniwersytetu Jagiellońskiego w Krakowie. (Sum.: Botanical Garden Museum in the Institute of Botany, the Jagiellonian University in Cracow), „Zeszyty Naukowe UJ. Opuscula Musealia” 1992, z. 6, s. 7-19. 
zamontowane elektryczne spirale grzewcze, a centralne ogrzewanie całego obiektu pojawiło się dopiero w 2014 roku. Remont konserwatorski parteru Collegium, przeprowadzony w latach 1995-1996 przez Zarząd Rewaloryzacji Zespołów Zabytkowych Krakowa, poprawił sytuację (restauracja całego obiektu zakończyła się w 2014 roku) ${ }^{12}$. Dokonano przebudowy zaplecza (Muzeum otrzymało inny pokój na główny magazyn), a także odnowienia sal ekspozycyjnych połączonego z pełnym przywróceniem ich historycznego charakteru. Wcześniej jeszcze urządzony został dział archiwalny, czyli „,historyczno-botaniczny” (il. II), do którego w następnych latach zaczęły napływać bogate materiały z krakowskiego Instytutu Botaniki oraz z innych ośrodków. Pozyskanie wielu nowych przedmiotów i archiwaliów różnego typu sprawiło, że z braku miejsca konieczne stało się zmniejszenie części dostępnej dla publiczności do czterech sal, na rzecz magazynów pełniących jednocześnie funkcję pracowni, które zajęły trzy pokoje. W Muzeum znajdowały się przez długi czas dwie duże szafy przekazane jako depozyt przez Instytut Botaniki, zawierające ok. 1000 okazów paleobotanicznych, odcisków i odlewów w materiale skalnym. Były w nich materiały Raciborskiego zebrane w kraju w okresie, kiedy pracował on jako asystent Ogrodu i stworzył podstawy polskiej paleobotaniki (permokarbońska flora wapienia karniowickiego, retycka flora tatrzańska), a także okazy wcześniejszego pioniera paleobotaniki Franciszka Tondery (1859-1926) (karbońska flora krakowskiego zagłębia węglowego). Kolekcje te zabrano, kiedy powstało w 2003 roku osobne Muzeum Paleobotaniczne Instytutu Botaniki przy ul. Kopernika 31 zorganizowane przed dr hab. Danutę Zdebską, dostępne głównie dla studentów i uczniów. Po zmianach organizacyjnych i zmianie nazwy zostało ono zlikwidowane w 2017 roku z powodu m.in. braku miejsca oraz przeniesienia części okazów do Centrum Edukacji Przyrodniczej w nowym Kampusie 600-lecia Odnowienia Uniwersytetu Jagiellońskiego.

Mimo skromnych warunków lokalowych udało się uratować część starych mebli (XIX-XX wiek), wyrzucanych w miarę modernizacji wyposażenia z Instytutu i z pawilonu dydaktycznego. Ostatnią partię pozyskano w 2017 roku, po przeniesieniu części Instytutu do budynku przy ul. Gronostajowej 3 w nowym Kampusie. Kiedy w 1997 roku udostępniono po remoncie piwnice Collegium, Muzeum otrzymało dwa pomieszczenia magazynowe użytkowane wspólnie z Ogrodem, a ściany korytarza i sali prelekcyjnej oraz konferencyjnej zakomponowano muzealnymi eksponatami. W 1994 roku Muzeum zyskało status pracowni oraz nazwę Muzeum Botaniczne i Pracownia Historii Botaniki im. J. Dyakowskiej (zmiany nazwy: od 2008 roku - Muzeum Ogrodu Botanicznego i Pracownia Historii Botaniki im. J. Dyakowskiej, od 2010 roku - Muzeum Ogrodu Botanicznego i Centrum Historii Botaniki im. J. Dyakowskiej). Nazwa upamiętniała zasługi Jadwigi Dyakowskiej (1905-1992), profesora Uniwersytetu Jagiellońskiego, paleobotanika i historyka botaniki, organizatorki i kierownika Biblioteki Instytutu Botaniki UJ (po wojnie połączonej z Biblioteką Zakładu, a później Instytutu Botaniki PAN). Prof. Dyakowska była entuzjastką pomysłu utworzenia stałej

${ }_{12}$ P. Köhler, A. Zemanek, Zespót pałacowy Collegium Śniadeckiego UJ Zakończenie rewaloryzacji [The Śniadecki Collegium JU, former palace The end of restoration], „Alma Mater”, czerwiec-wrzesień 2015, nr 175-176, s. 54-57. 
ekspozycji, a jej pomoc organizacyjna przyczyniła się do realizacji tej idei. W 2011 roku po likwidacji wszystkich pracowni na Uniwersytecie nastąpił powrót do dawnej nazwy - Muzeum Ogrodu Botanicznego UJ. Najnowsza sala ekspozycyjna „Świat tundry polarnej w Arktyce i Antarktyce" została urządzona w latach 2014-2018 przez prof. Marię Olech, z pomocą mgr Elżbiety Nowotarskiej. W 2018 roku Muzeum otrzymało dwa pokoje na II piętrze Collegium, przeznaczone na magazyn, a zarazem pracownię oraz pokój przygotowawczy do prelekcji organizowanych przez Ogród Botaniczny w sąsiedniej sali wykładowej.

Do sprawnego funkcjonowania jednostki przyczynili się oddani pracownicy. Należeli do nich: mgr Elżbieta Oleszak (Nogieć) (1981-1985) - pracownik techniczny; dr hab. Piotr Köhler (1985-2004) - historyk botaniki, pracownik techniczny, później naukowy (po odejściu z Muzeum prof. dr hab. w Instytucie Botaniki UJ) i dr Kamil Kulpiński (2007-2008, 2009-2014) - historyk botaniki, pracownik techniczny, później naukowy. Obecnie zatrudnieni są: mgr inż. Beata Sikora-Majewska (od 1989 roku) - pracownik techniczny i dr Piotr Klepacki (od 2004 roku) - etnobotanik, początkowo pracownik techniczny, obecnie naukowy. Wspomagają ich osoby pełniące inne obowiązki. Organizacją wystaw czasowych zajmuje się mgr Elżbieta Nowotarska (zatrudniona od 1974 roku) pracownik techniczny. W prace nad dokumentacją roślin Ogrodu i pomoc w sprawach muzealnych zaangażowany jest dr Bogusław Binkiewicz (od 2014 roku) - geograf roślin, zatrudniony na etacie technicznym. Funkcję opiekuna naukowego pełni prof. dr hab. Alicja Zemanek - historyk botaniki, pracująca od 1976 roku.

\section{Wybrane zasłużone osoby}

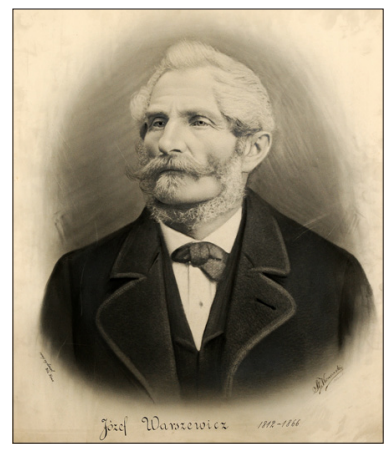

Il. 4. Józef Warszewicz.

Fot. St. Konarski.

Ze zbiorów Muzeum Ogrodu Botanicznego UJ
Józef Warszewicz (1812-1866) (il. 4)

Był w latach 1854-1866 głównym ogrodnikiem (inspektorem) Ogrodu Botanicznego Uniwersytetu Jagiellońskiego. W czasie pionierskich ekspedycji do Ameryki Środkowej i Południowej (1844-1850, 18501853) przesłał i przywiózł do Europy wiele tysięcy roślin, zwłaszcza storczyków, wśród których znalazło się wieleset nowych gatunków, opisanych przez badaczy zachodnioeuropejskich ${ }^{13}$. Pozyskane przez niego rośliny wzbogaciły ogrodowe zbiory. W Muzeum znajduje się stanowisko ekspozycyjne poświęcone roślinom związanym z Warszewiczem.

${ }^{13}$ A. Zemanek, Łowca roślin Józef Warszewicz (1812-1866) - w 200-lecie urodzin [Plant hunter Józef Warszewicz (1812-1866) - on the 200th anniversary of his birth], „Alma Mater”, grudzieństyczeń 2012-2013, nr 152-153, s. 43-46. 


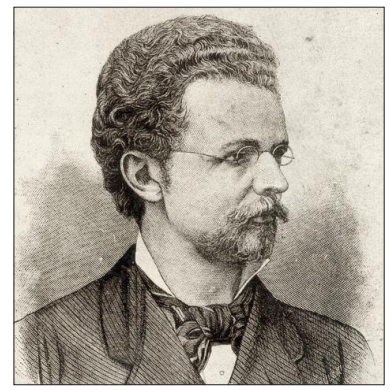

Il. 5. Józef Rostafiński. Ze zbiorów Muzeum Ogrodu Botanicznego UJ

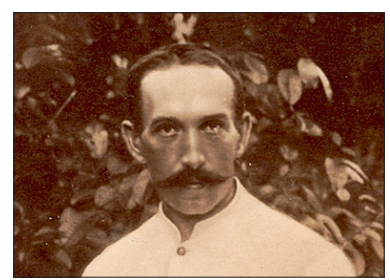

Il. 6. Marian Raciborski. Ze zbiorów Muzeum Ogrodu Botanicznego UJ

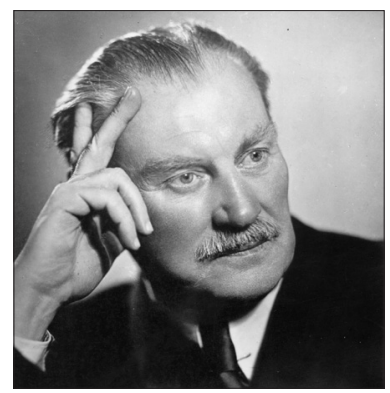

Il. 7. Władysław Szafer. Ze zbiorów Muzeum Ogrodu Botanicznego UJ
Józef Rostafiński (1850-1928) (il. 5)

Profesor Uniwersytetu Jagiellońskiego, taksonom roślin, historyk botaniki i biologii, dyrektor Ogrodu Botanicznego w latach 1878-1901 (formalnie do 1910). Opublikował pionierską monografię śluzowców, prowadził interdyscyplinarne badania $\mathrm{z}$ historii botaniki i innych nauk przyrodniczych, autorklasycznegodzieła na temat polskiej wiedzy przyrodniczej $\mathrm{w}$ średniowieczu ${ }^{14}$. W zbiorach muzealnych znajdują się źródła biograficzne oraz ogromne materiały dotyczące użytkowania roślin w jego czasach, zebrane dzięki ankiecie ${ }^{15}$.

\section{Marian Raciborski (1863-1917) (il. 6)}

Profesor Akademii Rolniczej w Dublanach, Uniwersytetu Lwowskiego i Uniwersytetu Jagiellońskiego, dyrektor Ogrodu Botanicznego (1912-1917), taksonom, geograf roślin, twórca polskiej paleobotaniki, pionier ochrony przyrody, odkrywca wielu nowych gatunków roślin i grzybów ${ }^{16}$. W czasie pobytu na Jawie w Indonezji (ówczesne Holenderskie Indie Wschodnie) w latach 1896-1900 zgromadził bogate zbiory muzealne, których część wystawiona jest na stałej ekspozycji.

\section{Władysław Szafer (1886-1970) (i1. 7)}

Profesor, rektor Uniwersytetu Jagiellońskiego, profesor Polskiej Akademii Nauk, geograf roślin, paleobotanik, historyk nauki, współorganizator ochrony przyrody w Polsce i Europie, dyrektor Instytutu Botaniki Uniwersytetu Jagiellońskiego, organizator i dyrektor Instytutu Botaniki Polskiej Akademii Nauk (obecnie Instytut Botaniki im. W. Szafera PAN). Jako dyrektor Ogrodu Botanicznego UJ przyczynił się do powiększenia jego obszaru, założenia wielu działów istniejących do dnia dzisiejszego oraz budowy dwóch kompleksów szklarniowych - storczykarni i szklarni Jubileuszowej ${ }^{17}$. Był też zasłużony dla Muzeum - zdobył wiele eksponatów, zwłaszcza z obszaru Polski.

${ }^{14}$ A. Zemanek, Koleje życia Józefa Rostafińskiego [w:] Józef Rostafinski botanik i humanista. (Sum.: Józef Rostafiński - a botanist and humanist), red. A. Zemanek, Kraków 2000, s. 19-106, ss. 30 nlb. (ilustracje).

${ }^{15}$ Wyniki ankiety opracowuje Piotr Köhler, który opublikował na ten temat wiele prac.

${ }^{16}$ A. Zemanek, Sto lat Instytutu Botaniki Uniwersytetu Jagiellońskiego (1913-2013). (Sum.: 100 years of Institute of Botany of the Jagiellonian University), Kraków 2013 [rozdział: Marian Raciborski (1863-1917). Systematyk, fitogeograf, paleobotanik], s. 232-235.

17 A. Zemanek, Sto lat Instytutu Botaniki... [rozdział: Władystaw Szafer (1886-1970). Fitogeograf, paleobotanik, wspóttwórca ochrony przyrody], s. 241-245. 


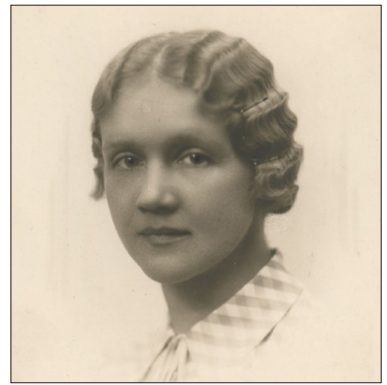

Il. 8. Jadwiga Dyakowska. Ze zbiorów Muzeum Ogrodu Botanicznego UJ

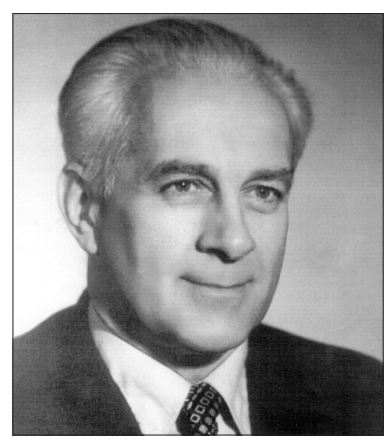

Il. 9. Jan Kornaś. Ze zbiorów Muzeum Ogrodu Botanicznego UJ

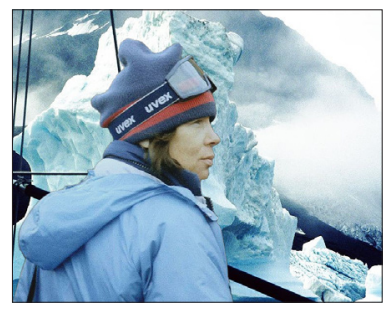

Il. 10. Maria Olech.

Ze zbiorów Muzeum Ogrodu Botanicznego UJ
Jadwiga Dyakowska (1905-1992) (il. 8)

Profesor Uniwersytetu Jagiellońskiego, paleobotanik i historyk botaniki, pionier palinologii, kynolog, organizator i wieloletni kierownik Biblioteki Instytutu Botaniki UJ (połączonej po wojnie z Biblioteką Zakładu, a później Instytutu Botaniki PAN) ${ }^{18}$. Przyczyniła się do realizacji idei urządzenia stałej ekspozycji, ofiarowała wiele archiwaliów. Spuścizna biograficzna J. Dyakowskiej znajduje się w zbiorach archiwalnych Muzeum.

\section{Jan Kornaś (1923-1994) (il. 9)}

Profesor Uniwersytetu Jagiellońskiego i Polskiej Akademii Nauk, geograf roślin, fitosocjolog i taksonom, dyrektor Instytutu Botaniki Uniwersytetu Jagiellońskiego, badacz szaty roślinnej Polski (szczególnie Karpat), pionier badań na temat synantropizacji szaty roślinnej. Wiele podróżował, m.in. do Afryki, gdzie badał paprotniki ${ }^{19}$. W czasie pobytu w Zambii (1971-1973) i Nigerii (1977-1978) zgromadził wraz z żoną Anną Medwecką-Kornaś, profesorem UJ i PAN, owoce i nasiona roślin sawannowych, które ofiarował do Muzeum. J. Kornaś i jego żona przekazali również wiele materiałów archiwalnych dotyczących Instytutu Botaniki UJ oraz fotografii związanych z ich życiem i działalnością naukową.

\section{Maria Olech (il. 10)}

Profesor Uniwersytetu Jagiellońskiego, lichenolog, organizatorka i kierownik Zakładu Badań i Dokumentacji Polarnej im. Prof. Zdzisława Czeppego w Instytucie Botaniki UJ. Terenem jej poszukiwań są Karpaty i obszary podbiegunowe. Uczestniczyła w kilkunastu wyprawach w okolice obydwu biegunów Ziemi. W Tatrach, w Arktyce i Antarktyce opisała (samodzielnie lub ze współpracownikami) ponad 100 nowych dla nauki taksonów porostów, grzybów naporostowych i autonomicznych, sinic i glonów, a także 5 nowych rodzajów ${ }^{20}$. Ofiarowała do Muzeum okazy polarne oraz zaaranżowała salę ,Świat tundry polarnej w Arktyce i Antarktyce".

${ }^{18}$ A. Zemanek, Sto lat Instytutu Botaniki... [rozdział: Jadwiga Dyakowska (1905-1992). Paleobotanik, historyk botaniki], s. 168-170.

19 A. Zemanek, Sto lat Instytutu Botaniki... [rozdział: Jan Kornaś (1923-1994). Fitogeograf, fitosocjolog, taksonom], s. 191-194.

${ }^{20}$ A. Zemanek, Sto lat Instytutu Botaniki... [rozdział: Maria Olech (ur. 1941)], s. 210-213. 


\section{Zbiory}

Muzeum posiada dwie kategorie zbiorów: botaniczne i historyczno-botaniczne. Na zbiory botaniczne liczące ok. 5400 okazów składają się: okazy dendrologiczne (przekroje i pnie drzew i krzewów) (il. III), karpologiczne (owoce i nasiona) (il. IV) oraz okazy mokre - całe rośliny zakonserwowane głównie w ok. 80\% spirytusie przechowywane w słojach i próbówkach. Osobną kategorię tworzą przedmioty użytkowe wykonane z produktów roślinnych. Materiały te zostały zebrane w Ogrodzie Botanicznym, a także na naturalnych stanowiskach w czasie wypraw badaczy do Afryki, Ameryki, Azji, Europy oraz w obszary polarne (XIX-XXI wiek). Do największych kolekcji z ekspedycji należą zbiory: zoologa i podróżnika Konstantego Jelskiego (1837-1896) (Ameryka Południowa - Peru, 1878-1879, ok. 200 okazów przechowywanych w szafce z napisem „Zbiór dendrologiczny Konstantego Jelskiego”), Mariana Raciborskiego (głównie z Jawy, 1896-1900, ok. 1250 okazów) ${ }^{21}$ oraz Marii Olech [Arktyka - Spitsbergen i Antarktyka Wyspa Króla Jerzego (Szetlandy Południowe) - koniec XX i początek XXI wieku - ok. 130 okazów]. Wśród najcenniejszych eksponatów znajdują się typy nomenklatoryczne grzybów jawajskich (okazy mokre), opisanych przez M. Raciborskiego (110 taksonów) ${ }^{22}$. Jedną z większych kolekcji tworzą drewna, owoce i nasiona gatunków użytkowych oraz innych obiektów, liczące łącznie kilkaset sztuk, przejęte w różnych latach od dawnego Muzeum Techniczno-Przemysłowego w Krakowie istniejącego w okresie 1868-195023. Do zbiorów botanicznych zalicza się także próbki materiałów pochodzenia roślinnego skrobi, soków różnych gatunków roślin, żywic itp. Podobnie traktowane są przedmioty użytkowe wykonane z drewna i włókien roślinnych. Z XIX wieku pochodzi ok. 1000 okazów, z wieku XX - ok. 1700. W ciągu kilkunastu lat naszego stulecia włączono do zbiorów 224 okazy. Dla reszty eksponatów botanicznych data zebrania nie jest udokumentowana ${ }^{24}$.

Osobną grupę tworzą zbiory historyczno-botaniczne, czyli archiwalne, dzięki którym Muzeum jest liczącym się miejscem dokumentacji polskiej botaniki, głównie krakowskiej. W ostatnich latach powiększyły się dzięki darom pracowników Instytutu i Ogrodu oraz osób z innych ośrodków, m.in. prof. dr. hab. Tomasza Majewskiego ze Szkoły Głównej Gospodarstwa Wiejskiego w Warszawie czy prof. dr. hab. Waldemara Żukowskiego z Uniwersytetu Adama Mickiewicza w Poznaniu. Przejęto też część spuścizn profesorów UJ, m.in. Jadwigi Dyakowskiej, Bogumiła Pawłowskiego (1891-1971), Józefa Rostafińskiego i Jana Walasa (1903-1991). Teczki archiwalne (ok. 1400 szt.) dotyczą

${ }^{21}$ P.S. Köhler, A. Zemanek, Zbiory Mariana Raciborskiego w Muzeum Ogrodu Botanicznego Uniwersytetu Jagiellońskiego. The Marian Raciborski collection in the Museum of the Jagiellonian University Botanic Garden, „Zeszyty Naukowe UJ. Prace Botaniczne” 1989, z. 18, s. 135-148.

${ }^{22}$ Ibidem, s. 141-142.

${ }_{23}$ P.S. Köhler, Zbiory dendrologiczne dawnego Krakowskiego Muzeum Techniczno-Przemysłowego w Muzeum Ogrodu Botanicznego Uniwersytetu Jagiellonskiego. The dendrological collection of the former Cracow Technical-Industrial Museum in the Museum of the Jagiellonian University Botanic Garden, „Wiadomości Botaniczne” 1990, vol. 34, nr 4, s. 70-72.

${ }^{24}$ A. Zemanek, P. Klepacki, Muzeum Ogrodu Botanicznego Uniwersytetu Jagiellońskiego..., Gołuchów 2017, s. 107-109. 


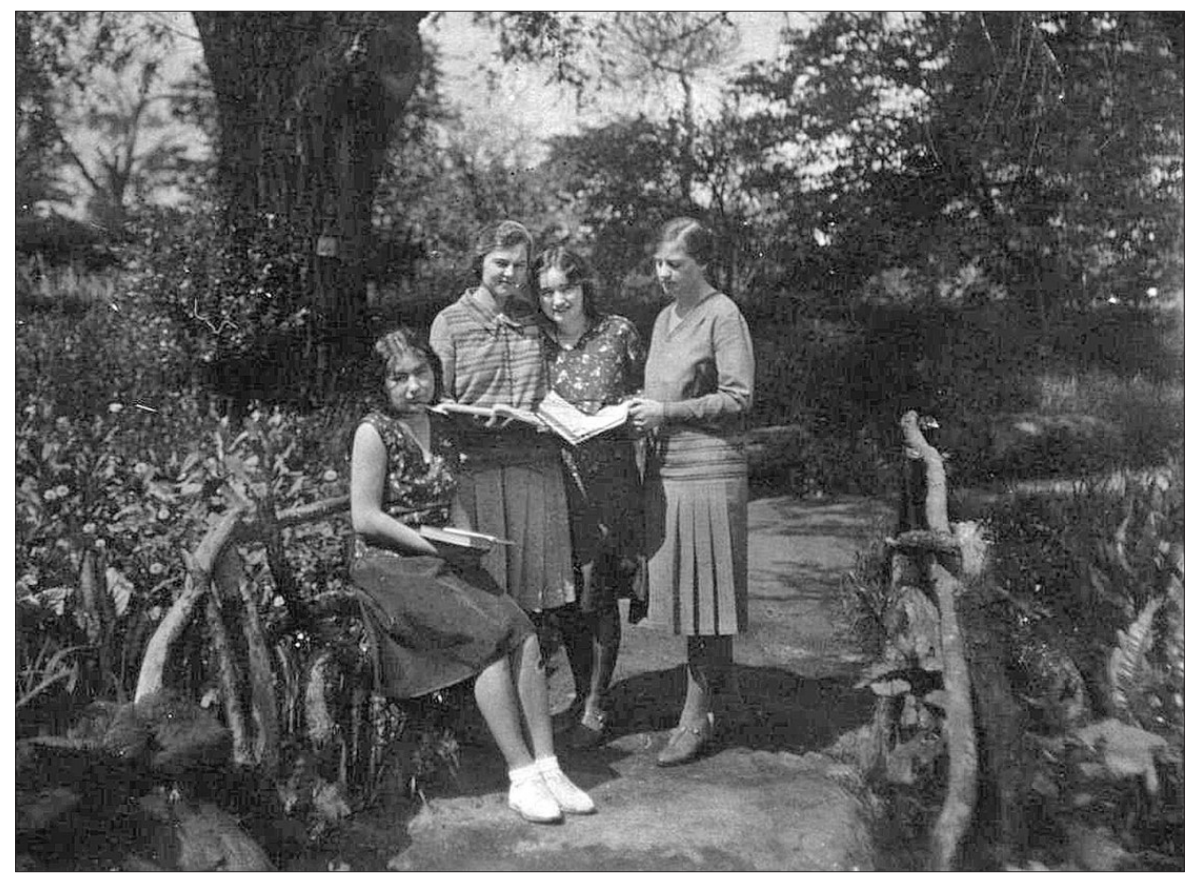

Il. 11. Uczennice w arboretum, maj 1930. Ze zbiorów Muzeum Ogrodu Botanicznego UJ

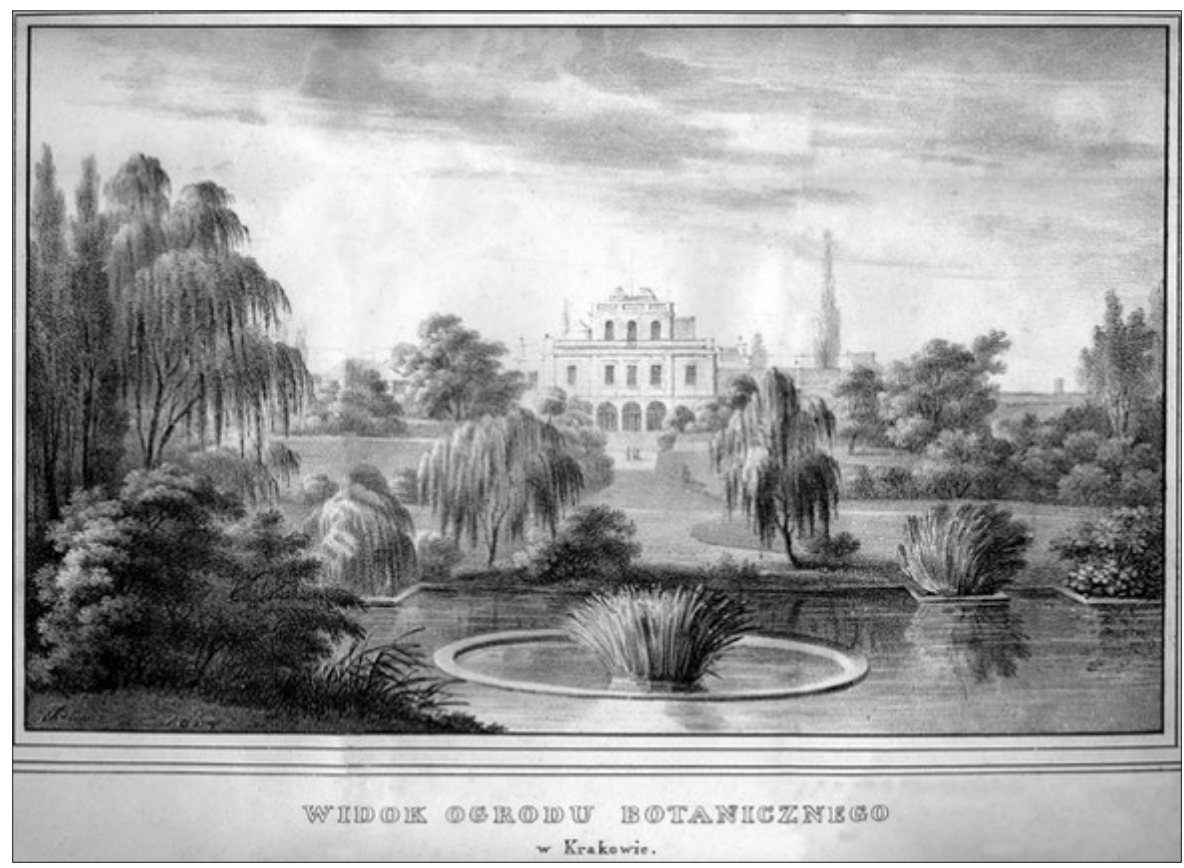

Il. 12. Widok Ogrodu Botanicznego od strony stawu. Jan Feliks Piwarski, 1834. Ze zbiorów Muzeum Ogrodu Botanicznego UJ 


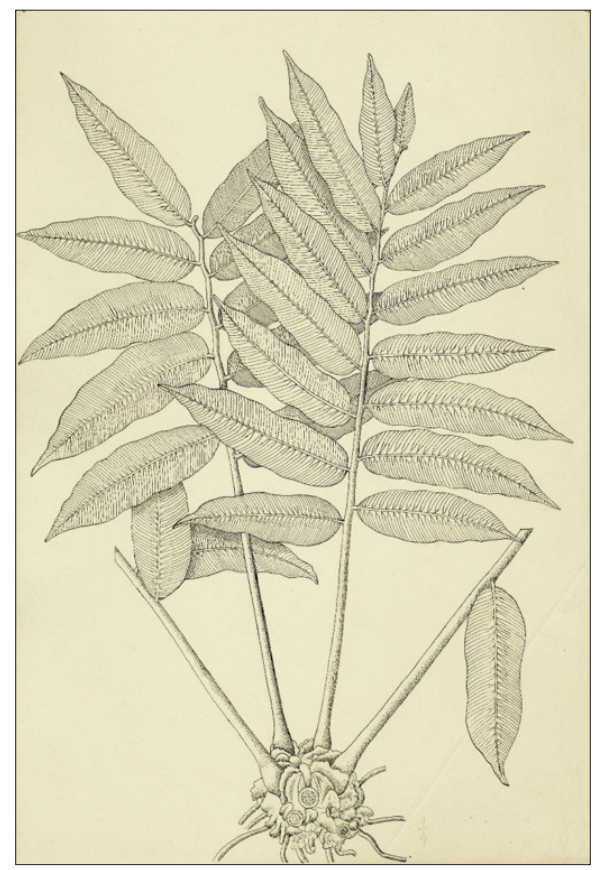

II. 13. Ilustracja liści paproci jawajskiej do pracy M. Raciborskiego Die Pteridophyten der Flora von Buitenzorg (Leiden, 1898). Ze zbiorów Muzeum Ogrodu Botanicznego UJ

Ogrodu Botanicznego, a także m.in. życia i działalności ok. 500 osób, głównie botaników ${ }^{25}$. Preparaty mikroskopowe (ok. 1500 szt.) dokumentują badania m.in. Mariana Raciborskiego i prof. Edwarda Janczewskiego (1846-1918) (ok. 700 szt.) - anatoma i taksonoma. Część preparatów wykorzystywano podczas ćwiczeń ze studentami. Unikatowe są dawne pomoce dydaktyczne używane w czasie zajęć w Uniwersytecie Jagiellońskim w XIX i XX wieku. Są to woskowe modele anatomiczne i owocników grzybów, modele kwiatów wykonane z blachy, masy papierowej, tektury, gipsu, drewna i innych materiałów (il. V) oraz organów rozmnażania roślin zarodnikowych, tablice drukowane lub rysowane przez różne osoby (łącznie ponad $200 \mathrm{sztuk})^{26}$. Materiały ikonograficzne obejmują kilkanaście tysięcy pozycji różnego typu: fotografii (il. 11), negatywów, slajdów, rycin (i1. 12), ilustracji botanicznych (il. 13), obrazów olejnych, akwarel i innych. Dział dokumentacji dźwiękowej i filmowej zawiera kilkadziesiąt jednostek. Najliczniejszy jest zbiór fotografii i negatywów dokumentujących działalność Ogrodu Botanicznego UJ w XX i XXI wieku.

${ }^{25}$ Dane liczbowe z 2017 roku. Wcześniejsze dane zawiera artykuł P. Köhlera: Zbiory archiwalne Muzeum Botanicznego i Pracowni Historii Botaniki im. J. Dyakowskiej Ogrodu Botanicznego Uniwersytetu Jagiellońskiego, „Krakowski Rocznik Archiwalny” 1999, t. 5, s. 190-197.

${ }^{26}$ Dane liczbowe z 2017 roku. Wcześniejsze zamieszczone w artykule P. Köhlera: Dziewiętnastowieczne pomoce naukowe w zbiorach Muzeum Ogrodu Botanicznego Uniwersytetu Jagiellońskiego. The 19th century educational appliances in the Museum of the Jagiellonian University Botanic Garden, „Wiadomości Botaniczne” 1991, vol. 35, nr 3/4, s. 96-99. 


\section{Stala ekspozycja}

\section{Sala 1 - Historia Ogrodu Botanicznego UJ}

Materiały dotyczące ponad 200-letniej historii Ogrodu znajdują się w gablocie stojącej w sali wejściowej pod oknem od strony tarasu. Wystawiona jest fotografia portretu Jana Jaśkiewicza (1749-1809), pierwszego dyrektora w latach 1783-1787. Z czasów kierownictwa Alojzego Estreichera, przypadających na lata 1809-1843, pochodzi plan Ogrodu z 1834 roku (rys. Jan Feliks Piwarski), plan kolekcji roślin wodnych na stawie urządzonej w 1822 roku, a także kopia ryciny Jana Feliksa Piwarskiego z 1834 roku przedstawiającej widok Ogrodu od strony stawu. Wyeksponowane są również najstarsze eksponaty muzealne, tj. naczynia wykonane z orzecha kokosowego: puchar rzeźbiony w barokowe ornamenty roślinne $\mathrm{z}$ datą 1687 , filiżanka ze spodkiem ozdobiona wypukło-rzeźbionym krajobrazem w stylu chińskim (Europa, ok. połowy XVIII wieku) oraz dwa kubki - wyroby ludowe z wybrzeża Zatoki Gwinejskiej w Afryce (przed 1800 rokiem) ${ }^{27}$. Profesorowi Władysławowi Szaferowi, jednemu z najbardziej zasłużonych dyrektorów, poświęcona jest „szafa biograficzna”. Można w niej obejrzeć duży portret fotograficzny, zdjęcia z wycieczek i badań terenowych, pionierskie publikacje z fitosocjologii i paleobotaniki, dwa niezrealizowane gipsowe modele pomnika uczonego, medal wybity z okazji 100-lecia urodzin W. Szafera i 30-lecia Instytutu Botaniki im. W. Szafera Polskiej Akademii Nauk, według projektu J. Adamczyka, a także osobiste przedmioty profesora: biret rektorski, teczkę i laskę, której używał w późniejszym wieku, oprowadzając zwiedzających po Ogrodzie. Tło dla ekspozycji historycznej tworzą okazy dendrologiczne stojące na podłodze oraz zawieszone na ścianach. Na przekroju ogromnego pnia jodły pospolitej (Abies alba Mill.), która rosła w Górach Świętokrzyskich w latach ok. 1767-1950 zaznaczono najważniejsze wydarzenia z dziejów krakowskiego Ogrodu Botanicznego. Najnowszym eksponatem jest oryginalnie ukształtowany przekrój pnia ok. 150-letniego buka zwyczajnego (Fagus sylvatica L.) - jednego z najpiękniejszych drzew w arboretum, powalonego w czasie huraganu w 2013 roku (na jego tle siedzi prof. Janina Kraupe w czasie wernisażu w Muzeum, zob. il. VIII). Przy wejściu stoi „,szafka dendrologiczna" wyłożona próbkami ok. 260 krajowych i obcych gatunków drzew i krzewów. Wykonał ją w 1840 roku warszawski stolarz Wojciech Hubicki, na zamówienie zoologa Antoniego Wagi (1799-1890).

\section{Sala 2 - Świat tundry polarnej w Arktyce i Antarktyce}

Eksponaty z najnowszych czasów wystawione są w sali ,Świat tundry polarnej w Arktyce i Antarktyce”. Prof. dr hab. Maria Olech - lichenolog, znana polarniczka, zebrała porosty i inne organizmy żyjące w tundrze polarnej, w czasie ekspedycji odbytych pod koniec XX i na początku XXI wieku. Przebywała na Spitsbergenie (dwie stacjonarne

\footnotetext{
${ }^{27}$ P. Köhler, Najstarsze zbiory Muzeum Ogrodu Botanicznego..., s. 76.
} 
wyprawy Uniwersytetu Jagiellońskiego), uczestniczyła w pięciu arktycznych francusko-polskich rejsach na jachcie „Vagabond'elle” wokół bieguna północnego. Długi czas spędziła w Antarktyce, biorąc udział w 12 wyprawach Polskiej Akademii Nauk do Stacji im. Henryka Arctowskiego na Wyspie Króla Jerzego (Szetlandy Południowe) oraz w 23. hinduskiej wyprawie do Stacji „Maitri” w Oazie Schirmachera na kontynencie Antarktydy.

Okazy porostów, mchów i roślin kwiatowych pochodzących z okolic obydwu biegunów, umieszczone są w trzech szafach i dwóch gablotach. Na pięciu posterach znajdują się teksty omawiające zagadnienia związane z życiem roślinnym w warunkach polarnych, zilustrowane mapą świata z zaznaczoną Arktyką i Antarktyką. Można przeczytać, że porosty, czyli grzyby zlichenizowane, są wynikiem symbiozy grzybów i glonów. Mają dużą odporność na ekstremalne warunki klimatyczne, dzięki temu mogą żyć w niskich temperaturach, na ubogim podłożu, przy długim okresie zalegania śniegu. Są ważnym składnikiem tundry - formacji roślinnej pozbawionej drzew, z dominującym udziałem roślin zarodnikowych. Na ekspozycji dużo miejsca poświęcono podobieństwom i różnicom między tundrą arktyczną i antarktyczną. W tundrze arktycznej, oprócz porostów (ok. 2000 gatunków) i mchów (ok. 600 gatunków) występuje wiele roślin kwiatowych, m.in. skalnice, wierzby i trawy. Znacznie uboższa jest tundra w Antarktyce, w której rosną tylko dwa gatunki roślin kwiatowych, a także głównie porosty (ok. 450 gatunków) i mchy (111 gatunków). Szafy oznaczone zielonymi znacznikami zawierają organizmy arktyczne, błękitnymi - pochodzące z Antarktyki. Jaskrawopomarańczowe porosty ornitokoprofilne rosnące na antarktycznych skałach nadmorskich, nawożone odchodami pingwinów i innych ptaków, pokazane są w gablocie pod oknem. Jeden z porostów arktycznych mający włosowatą plechę, porastający mchy na morenach lodowcowych, wystawiony w szafie arktycznej - to gatunek nowy dla nauki opisany w 2004 roku przez Marię Olech i Jana Bystrka. Jego nazwa Bryoria forsteri Olech \& Bystr. upamiętnia przyrodnika i podróżnika Jana Jerzego Forstera (1754-1794), poddanego króla Polski, członka drugiej wyprawy Jamesa Cooka naokoło świata. W szafie poświęconej roślinom kwiatowym, oprócz dziesięciu okazów pochodzących z Arktyki, znajdują się dwa endemiczne gatunki antarktyczne: kolobant antarktyczny - Colobanthus quitensis (Kunth) Bartl. - poduszkowa roślina z rodziny goździkowatych i trawa śmiałek antarktyczny Deschampsia antarctica É. Desv., a także nowy przybysz - wiechlina roczna (Poa annua L.) - kosmopolityczna trawa zawleczona przez człowieka. Interesujące zestawienie znajduje się w gablocie pod ścianą, w której Maria Olech odtworzyła małe fragmenty tundry arktycznej i antarktycznej, z luźno usypanymi kamieniami, spomiędzy których wyłaniają się zasuszone, urozmaicone kolorystycznie porosty krzaczkowate i skorupiaste, mchy, widłaki i rośliny kwiatowe (tundra arktyczna) oraz różnie fragmenty skał okrytych krzaczkowatymi i skorupiastymi porostami, a wśród nich kępa trawy śmiałka antarktycznego (tundra antarktyczna).

\section{Sala 3 - Przybudówka z witrażami-Rośliny nagozalą̇̇kowe}

W niewielkiej, półokrągłej przybudówce, ozdobionej dwoma okiennymi witrażami - okrągłym i owalnym, urządzona jest ekspozycja roślin nagozalążkowych. Dwie wiszące gabloty i podest poświęcone są sagowcom (klasa Cycadopsida) z podgromady 
nagozalążkowych wielkolistnych (Cycadophytina), zwanym „dinozaurami roślinnego świata". Jest to reliktowa grupa systematyczna, szeroko rozpowszechniona na Ziemi w erze mezozoicznej, dzisiaj wymierająca, rozmieszczona w obszarach tropikalnych i subtropikalnych. Gablota po lewej stronie od wejścia zawiera ogólne informacje, mapę współczesnego rozmieszczenia sagowców oraz m.in. spreparowane fragmenty ich organów rozmnażania, tzw. szyszek żeńskich, czyli makrostrobili, oraz męskich - mikrostrobili. Kolekcja kilkudziesięciu żywych sagowców uprawianych w szklarni Jubileuszowej krakowskiego Ogrodu Botanicznego, wśród których są stare, XIX-wieczne okazy, cieszy się europejską renomą. Pierwsze rośliny z tej grupy odnotowane są w spisie gatunków z 1809 roku, a jej rozwój Ogród zawdzięcza Józefowi Warszewiczowi, który odkrył trzy sagowce z rodzaju Zamia. Fotografie najstarszych egzemplarzy znajdują się w innej gablocie. Na podeście wyeksponowane są w plastikowych pojemnikach duże strobile, czyli tzw. szyszki sagowców, które są plonem ogrodowych upraw, m.in. ponad 45-centymetrowa „szyszka męska”, czyli mikrostrobil gatunku Cycas circinalis L., którego rysunek znajduje się w godle krakowskiego Ogrodu Botanicznego. „Drzewa i krzewy szpilkowe (iglaste) w Polsce" prezentuje gablota zawierająca próbki drewna, szyszki, pokrojowe ryciny oraz mapki zasięgów kilku rodzimych gatunków. Zróżnicowaniu morfologii szyszek poświęcona jest gablota „Sosna (Pinus)”. „Rośliny nagozalążkowe w Ogrodzie Botanicznym UJ" scharakteryzowane są w stojącej gablocie zawierającej zestawienie liczbowe uprawianych gatunków, plan z zaznaczonymi najcenniejszymi okazami oraz szerszymi wiadomościami na temat rzadkich, reliktowych azjatyckich drzew - ich piękne stare okazy są ozdobą ogrodowego krajobrazu. Jest to miłorząb dwuklapowy (Ginkgo biloba L.) - wyeksponowano fotografie, liście i nasiona - oraz metasekwoja chińska (Metasequoia glyptostroboides Hu \& W.C. Cheng) przedstawiona na fotografiach, obok których umieszczono szyszki. Duże walory estetyczne ma ok. 500-letni pień cisa pospolitego (Taxus baccata L.) (zob. il. III), gatunku chronionego w Polsce. To potężne drzewo rosło niegdyś we wsi Łętownia w dawnym powiecie wadowickim - pień został przywieziony do Krakowa w 1918 roku.

\section{Sala 4 - Botanika tropikalna w Krakowie}

W Krakowie od dawna uwidacznia się zainteresowanie botaniką tropikalną, której zagadnienia przedstawione są w największej, sześciokątnej sali (il. VI).

Ameryka Środkowa i Poludniowa - Józef Warszewicz

Stolik ekspozycyjny po lewej stronie od wejścia zawiera materiały związane z Józefem Warszewiczem (1812-1866), podróżnikiem i zbieraczem roślin w Ameryce Środkowej i Południowej. Jego pierwszy pobyt w Ameryce obejmował lata 1844-1850. Prawdopodobnie przemierzył wówczas tereny od Gwatemali, poprzez Honduras i Nikaraguę, do Kostaryki i Panamy. W czasie drugiej podróży (1850-1853) przebył m.in. obszary w Panamie, Ekwadorze, Peru i Boliwii, a także być może w Brazylii. W większości miejsc był pierwszym Europejczykiem zbierającym rośliny, które wysyłał do czołowych ogrodów 
botanicznych i szkółek ogrodniczych, m.in. w Berlinie, Brukseli, Hamburgu, Londynie i Zurychu. Na podstawie jego materiałów opisano setki nowych gatunków, zwłaszcza storczyków. Dla upamiętnienia zasług Warszewicza botanicy utworzyli co najmniej 70 nazw roślin, m.in. nazwy rodzajowe Warszewiczia z rodziny Rubiaceae i Warszewiczella (obecnie Cochleanthes) z rodziny Orchidaceae. Na stoliku ekspozycyjnym znajduje się publikacja Stefana Ziobrowskiego ${ }^{28}$ na temat roślin nazwanych na cześć Warszewicza, a także kopie rycin trzech gatunków: Maranta warszewiczii hort. ex Planch. - obecnie Calathea warscewiczii (L. Mathieu) Planch. \& Linden oraz storczyków: Cattleya warscewiczii Rchb.f. i Cyrtopodium andersonii (Lamb. ex Andrews) R. Br. Żywy okaz tego ostatniego gatunku zebrany przez Warszewicza w Wenezueli i przywieziony do krakowskiego Ogrodu przetrwał do dzisiejszego dnia w szklarni Holenderce. Na stoliku znajduje się kopia tableau zawierającego fotografię pomnika Warszewicza w Ogrodzie, zdjęcie botaników i ogrodników zrobione pod pomnikiem oraz fotografię wielu osób przy grobie podróżnika na cmentarzu Rakowickim w czasie uroczystości stulecia urodzin obchodzonych w 1913 roku. Tableau z datą 1 stycznia 1914 roku opatrzone jest dedykacją pracowników dla Mariana Raciborskiego.

Jawa (Indonezja) - zbiory Mariana Raciborskiego

Największe muzealne zbiory tropikalne zgromadzone przez Mariana Raciborskiego zostały wyeksponowane w siedmiu oszklonych, XIX-wiecznych szafach. Raciborski, po studiach na Uniwersytecie Jagiellońskim oraz uzyskaniu doktoratu na Uniwersytecie w Monachium, przebywał w latach 1896-1900 roku na Jawie, należącej wówczas do Holenderskich Indii Wschodnich (obecnej Indonezji) ${ }^{29}$. Początkowo pracował (1896-1897) w Ogrodzie Botanicznym (s'-Lands Plantentuin) w Buitenzorgu (obecnym Bogorze) - założonym w 1817 roku sławnym ośrodku botaniki tropikalnej, zaangażowany przez dyrektora placówki, Melchiora Treuba (1851-1910) do opracowania flory paprotników zachodniej Jawy. Po jej ukończeniu zatrudniony został najpierw w Stacji Doświadczalnej do Badań Trzciny Cukrowej w Kagok pod Tegalem (1897-1898), a następnie w Stacji Hodowli Tytoniu w Wedi koło Klaten (1898-1900), na Jawie Środkowej. Prowadził wówczas badania z zakresu botaniki stosowanej nad pasożytniczymi organizmami niszczącymi plantacje trzciny cukrowej i tytoniu. Jego studia doprowadziły do odkrycia wielu nowych taksonów glonów i grzybów. Ponieważ interesował się poezją i był wielbicielem twórczości Adama Mickiewicza i Juliusza Słowackiego, niektórym glonom i grzybom nadał nazwy, które były imionami literackich bohaterów: np. Aldona, Alina, Anhellia, Balladyna, Gerwasia, Goplana, Skierka, Telimena. Prowadził również badania nad zagadnieniami botaniki tropikalnej, m.in. dotyczące anatomii i ekologii lian i epifitów. W wolnych chwilach podróżował po Jawie i okolicznych wyspach, odwiedził

${ }^{28}$ S. Ziobrowski, Rośliny nazwiskiem J. Warszewicza oznaczone, „Ogrodnictwo” 1927, R. 23, z. 1, s. $14-25$.

29 A. Piekiełko-Zemanek, Kalendarium życia Mariana Raciborskiego. A calendar of life of Marian Raciborski [w:] Marian Raciborski. Studia nad życiem i działalnością naukowa De Mariani Raciborski vita et scriptis, red. J. Kornaś, Warszawa-Kraków 1986, s. 9-43, tabl. - k. 1 nlb. 
m.in. Sumatrę (1896) i Krakatau (1897). Zbierał rośliny do zielnika, próbki drewien, owoce, nasiona oraz konserwował całe rośliny do celów muzealnych. Interesował się też sztuką malajską, szczególnie teatrem. Kolekcjonował marionetki tradycyjnego teatru jawajskiego, starą broń, zwłaszcza sztylety, tzw. krisy, przedmioty codziennego użytku i inne obiekty. Zbiory te znajdują się obecnie w Muzeum Etnograficznym im. Seweryna Udzieli w Krakowie. Współczesne kopie dwóch marionetek stoją na szczycie jednej z muzealnych szaf z okazami botanicznymi.

W środkowej szafie naprzeciw wejścia zgromadzone są materiały dotyczące działalności Raciborskiego w Indonezji - kopia jego fotografii w tropikalnym stroju (zob. il. 6), schematyczna mapa Jawy z zaznaczonymi miejscowościami, w których pracował, oryginalna fotografia Pajdana (Pajdan, Pa Idan) - ogrodnika Ogrodu Botanicznego w Buitenzorgu, towarzysza wycieczek Raciborskiego, a także zdjęcie domu, w którym mieszkał w Kagok pod Tegalem. Można też zobaczyć kopię karty tytułowej i jednej ze stron sławnej monografii Die Pteridophyten der Flora von Buitenzorg (Leiden 1898) ${ }^{30}$, która zawiera opisy 385 gatunków i 11 odmian, w tym dziesięciu gatunków i dwóch odmian nowych dla nauki. Oprócz tego pokazane są kopie dwóch kolorowych pasteli przedstawiających badane pasożytnicze grzyby, namalowane przez R. Soedirmana, a także słój oraz szklane fiolki w statywie zawierające materiały do badań zakonserwowane w spirytusie, teczkę z preparatami mikroskopowymi oraz dwa metalowe koszyki z próbówkami. W pozostałych szafach wyeksponowane są okazy, które służyły do badań oraz do celów dydaktycznych - niektóre były używane później przez Raciborskiego i jego uczniów do demonstracji w czasie wykładów i ćwiczeń w Akademii Rolniczej w Dublanach, w Uniwersytecie Lwowskim i Uniwersytecie Jagiellońskim. Zgrupowane są według następujących zagadnień: drzewa i krzewy Jawy, owoce tropikalnych roślin użytkowych, wyroby z surowców roślinnych, pasożytnicze rośliny kwiatowe, epifity oraz liany.

W szafie prezentującej wyroby z surowców roślinnych znajdują się papiery z włókna palmowego, przedmioty z pędów bambusa - wazon oraz pułapka na ptaki, a także używany przez Raciborskiego w czasie wykładów wskaźnik wystrugany z bambusowego pędu. Można tu również obejrzeć próbkę pachnących korzeni trawy Chrysopogon zizanioides (L.) Roberty [Vetiveria zizanioides (Presl) Ohwi] uprawianej w Azji Południowo-Wschodniej, stosowanej w przemyśle perfumeryjnym, w koszykarstwie oraz do wyrobu mat. Wyeksponowana jest trzepaczka z korzeni tej trawy oraz zamykana skrzynka. W szafie z przekrojami pni drzew i krzewów znajduje się schematyczna mapa roślinności Jawy, pokazująca, że naturalne zbiorowiska, takie jak lasy monsunowe, lasy tekowe (teakowe), namorzyny (mangrowe), tropikalne lasy deszczowe i inne, zajmują stosunkowo niewiele miejsca w porównaniu z polami uprawnymi, głównie ryżowymi. O niszczeniu pierwotnej przyrody przez człowieka wspominał już Raciborski. Wystawiony jest fragment spłaszczonego pnia tropikalnego drzewa Dipterocarpus retusus Blume (D. trinervis Bl.) wraz z jego dużymi owocami z aparatem lotnym ułatwiającym rozsiewanie. Znajduje się tu również przekrój pnia drzewa tekowego (teakowego) (Tectona grandis L.) należącego do ważnych bogactw naturalnych Archipelagu Malajskiego, zwłaszcza Jawy - twarde drewno, odporne na działanie wody, używane jest w budownictwie okrętowym i meblarstwie. Najsławniejszy owoc Indonezji - durian właściwy

\footnotetext{
${ }^{30}$ M. Raciborski, Die Pteridophyten der Flora von Buitenzorg, Leiden 1898.
} 
(Durio zibethinus Murr.) - zakonserwowano w słoju, a obok widnieje jego współczesny okaz suchy oraz rysunek. Jest to kolczasta torebka zawierająca nasiona z mięsistą, jadalną osnówką o znakomitym smaku i bardzo nieprzyjemnym zapachu, przyciągającym duże ssaki, m.in. niedźwiedzia malajskiego, chętnie spożywana również przez człowie$\mathrm{ka}$ - owoce sprzedawane są na targach w zamkniętych torebkach.

W szafie z pasożytniczymi roślinami kwiatowymi na uwagę zasługuje słój z młodymi, ogromnymi kwiatami bukietnicy (Rafflesia rochussenii T. et B.) pasożytującej na korzeniach lian z rodzaju Tetrastigma, występującej w wilgotnych lasach tropikalnych zachodniej Jawy. Raciborski interesował się szczególnie epifitami (poroślami) i lianami charakterystycznymi dla lasów tropikalnych. W szafie poświęconej epifitom znajduje się słój ze świetnie zachowanymi okazami gatunku Dischidia major (Vahl) Merr. (D. rafflesiana Wall.) występującego w lasach tekowych i wtórnych Jawy. Rośnie on bez kontaktu z ziemią, przyczepiony do gałęzi wysoko w koronach drzew, i wytwarza „własne doniczki", tzn. liście, przekształcone w wydłużone urny, do których wrastają korzenie. Gromadzi się w nich woda opadowa oraz gleba przyniesiona przez żyjące wewnątrz kolonie mrówek. Poniżej wystawiony jest w słoju epifit myrmekofilny Hydnophytum formicarum Jack - roślina z bulwami pędowymi mającymi wewnątrz puste przestrzenie zamieszkiwane przez mrówki. Bogato reprezentowane są liany - fragmenty poskręcanych pędów, przekroje ukazujące ich budowę anatomiczną, kolce i ciernie czepne, a także XIX-wieczne fotografie tych roślin przywiezione z Jawy. Większe, efektowne okazy wyeksponowane są na osobnej tablicy. Ponad szafami zawieszone są koliście zwinięte pędy różnych lian, m.in. jedynej pnącej palmy z rodzaju Calamus sp. - do tego rodzaju należy kalamus rotangowy (Calamus rotang L.) (rattan) używany do wyrobu mebli trzcinowych (surowiec nosi nazwę rattanu lub rotangu).

\section{Afryka}

\section{Zbiory Jana Kornasia i Anny Medweckiej-Kornaś}

Na środku sali stoi sześciokątna dwupoziomowa gablota ze zbiorami owoców i nasion roślin sawannowych Afryki przywiezionych przez profesora Jana Kornasia, geografa roślin, fitosocjologa i taksonoma, który wykładał na uniwersytetach w Lusace w Zambii (1971-1973) oraz w Maiduguri w Nigerii (1977-1978), uczestniczył też przez miesiąc (w 1976 r.) w wyprawie „Kilimandżaro 75”31. W czasie pobytu w Afryce przez dłuższy czas towarzyszyła mu żona Anna Medwecka-Kornaśs ${ }^{32}$ - ekolog i fitosocjolog, profesor UJ i PAN, prowadząca badania m.in. na temat roli ognia w funkcjonowaniu zbiorowisk sawannowych, a także uczestnicząca w gromadzeniu zbiorów. Jan Kornaś należał do uznanych afrykańskich pteridologów. Opublikował m.in. monografię na temat rozmieszczenia i ekologii paprotników w Zambii (1979), był współautorem opracowań dotyczących

${ }^{31}$ A. Zemanek, Sto lat Instytutu Botaniki..., [rozdział: Jan Kornaś (1923-1994). Fitogeograf, fitosocjolog, taksonom], s. 191-194.

32 A. Zemanek, Sto lat Instytutu Botaniki..., [rozdział: Anna Medwecka-Kornaś (ur. 1923). Ekolog, fitosocjolog], s. 205-207. 
rozmieszczenia paprotników w Rwandzie (1993) oraz w południowo-wschodniej części Republiki Konga (2000) - tę drugą pracę obejmującą oznaczone przez niego materiały zebrane przez Belgów napisała po jego śmierci żona. Na dolnym poziomie gabloty wystawiona jest fotografia profesora Kornasia w terenowym stroju stojącego przy samochodzie. Na schematycznej mapie Afryki zaznaczone są kraje, gdzie zbierał rośliny do zielnika: Zambia, Tanzania, Kenia, Etiopia w latach 1971-1973 oraz 1976, a także Nigeria i Kamerun w okresie 1977-1978 (zgromadził łącznie ok. 5600 arkuszy zielnikowych). Jeden $\mathrm{z}$ arkuszy znajduje się $\mathrm{w}$ gablocie. Wystawiono też kserokopie pierwszych stron dwóch publikacji - na temat ekologii paprotników Zambii (1977) oraz pracy zawierającej opis nowego gatunku paproci, nazwanego na cześć żony (1978) ${ }^{33}$. Hełm tropikalny, wykonany z różnych włókien roślinnych, m.in. palmowych, pochodzi z Wietnamu, który J. Kornaś odwiedził w 1963 roku. Oryginalnym afrykańskim eksponatem jest wyrób ludowy z Zambii - sieć na ryby z pędów turzyc. Na dolnym poziomie gabloty znajdują się rośliny rozsiewane przez zwierzęta, m.in. duży kilkunastocentymetrowy owoc baobabu właściwego (Adansonia digitata L.) - długowiecznego drzewa suchych lasów sawannowych, o niezwykle grubym pniu magazynującym wodę. Owoce zjadane i rozsiewane przez zwierzęta (głównie słonie) wykorzystywane są również przez człowieka (jadalne nasiona oraz wewnętrzna gąbczasta tkanka owocu używana jest m.in. do wyrobu napojów). Interesującą rośliną jest modligroszek różańcowy (Abrus precatorius L.) liana występująca w Afryce tropikalnej, mająca strąki z czerwonymi nasionami zjadanymi przez ptaki i przez nie rozsiewana. Nasiona cechujące się wyrównanym ciężarem $(0,14 \mathrm{~g})$ używane były przez tubylców jako odważniki oraz do wyrobu naszyjników i różańców. Łupina nasienna zawiera silnie trujący alkaloid - abrynę - i stosowana była do zatruwania strzał. Na górnym poziomie gabloty wyeksponowane są m.in. gatunki rozsiewane przez wiatr, np. liana Dioscorea sp. mająca oskrzydlone owoce (torebki), z nasionami wytrząsanymi podmuchami wiatru. Duże oskrzydlone owoce drzewa z rodzaju Combretum toczone są po sawannie przez wiatr na duże odległości (dlatego zaliczane są do tzw. biegunów).

\section{Wyprawa ,Kilimandżaro 75 ,}

Po prawej stronie od wejścia znajduje się tablica i stolik ekspozycyjny poświęcone wyprawie „Kilimandżaro 75” do Afryki Wschodniej, która odbyła się w latach 1975-1976 ${ }^{34}$. Była to naukowo-alpinistyczna ekspedycja trwająca około siedmiu miesięcy - pierwsza polska wyprawa tego typu na południe od Sahary. Zorganizowana została przez Oddział Krakowski PTTK, Ośrodek Telewizji w Krakowie i redakcję gazety „Echo Krakowa”, pod patronatem rektora Uniwersytetu Jagiellońskiego prof.

33 J. Kornaś, Life forms and seasonal patterns in the pteridophytes in Zambia, „Acta Societatis Botanicorum Poloniae" 1977, vol. 46, nr 4, s. 669-690; J. Kornaś, A new species of Athyrium (Aspleniaceae) from Zambia, „Kew Bulletin” 1978, vol. 33, nr 1, s. 99-101.

${ }^{34}$ Informacje od prof. dr. hab. Bogdana Zemanka, a także z Muzeum Ogrodu Botanicznego UJ: sygn. OB-43 - Wyprawy naukowe: m.in. Wyprawa pracowników Ogrodu Botanicznego do Afryki, 1975; sygn. OB-93 - Wyprawa Kilimandżaro 75. Materiały różne [Proporzec wyprawy]; sygn. B-109wśród innych materiałów: I. Bobbé, Kilimandżaro-75, „WTK” 33(1129), 15 VIII 1976, ss. 2 nlb. 
dr. hab. Mieczysława Karasia dzięki wsparciu społecznemu wielu instytucji i zakładów pracy, m.in. Polfy i Towarzystwa Ogrodniczego w Krakowie. Uczestniczyło w niej 12 osób, w tym kierownik dr Jerzy Brzozowski (geolog), oraz biologowie: doc. dr hab. Kazimierz Szczepanek (paleobotanik), mgr Bogdan Zemanek (geograf roślin) - w późniejszych latach profesorowie Uniwersytetu Jagiellońskiego, i dyrektorzy Ogrodu Botanicznego, mgr Kazimierz Strzałka (entomolog i fizjolog roślin), późniejszy profesor UJ, dyrektor Instytutu Biologii Molekularnej, dziekan Wydziału Biotechnologii, organizator i dyrektor Małopolskiego Centrum Biotechnologii, oraz prof. Jan Kornaś, który przez miesiąc towarzyszył wyprawie w Kenii i Tanzanii. Trasa prowadziła z Polski statkiem „Władysław Łokietek” przez Kanał Sueski, Jordanię, Arabię Saudyjską, Sudan do Kenii, gdzie uczestnicy przesiedli się do ciężarówki Star 266. Program naukowy obejmował głównie teren Kenii, Tanzanii i Ugandy. Odwiedzono kilka parków narodowych, m.in. Ngorongoro i Serengetti w Tanzanii. Wybrane osoby zdobyły najwyższe szczyty afrykańskie: Kilimandżaro (5895 m n.p.m.), Mount Elgon (4321 m n.p.m.) - drugie polskie zdobycie tego szczytu, Mount Kenya (5199 m n.p.m.) oraz Mount Meru (4567). Droga powrotna prowadziła przez Ugandę, Sudan, Republikę Środkowej Afryki, Czad, Nigerię, Niger, Algierię do Francji, a stamtąd przez Włochy, Austrię i Czechosłowację do Polski. Część powrotnego szlaku wiodła przez Saharę. Warto podkreślić, że była to ostatnia polska wyprawa, która przejechała kraje Afryki od Tanzanii do Algierii - dzisiaj, ze względu na trudną sytuację polityczną panującą w niektórych spośród nich, jest to niemożliwe. Plon ekspedycji był bogaty - zgromadzono zielnik (ok. 3000 arkuszy roślin naczyniowych, ok. 250 próbek mchów i porostów), owoce i nasiona oraz żywe rośliny ok. 150 gatunków dla ogrodowych szklarni i dla muzeum, a także ok. 1500 owadów. Ponadto wykonano setki fotografii i przezroczy, które w następnych latach wykorzystywano podczas wykładów na Uniwersytecie Jagiellońskim i prelekcji w różnych gremiach. Na tablicy wyeksponowana jest mapa podróży, fotografia uczestników zrobiona na równiku przekroczonym w Kenii oraz okazy botaniczne. Jednym z najcenniejszych drzew Afryki Wschodniej jest Dalbergia melanoxylon Guill. et Perr. zwane „,afrykańskim” lub „fałszywym” hebanem. Ma piękne, dwukolorowe drewno - jasne w peryferycznych częściach pnia, czarne w części centralnej - używane jest do wyrobu luksusowych przedmiotów, a także w rzeźbiarstwie. Na tablicy wystawiono próbkę drewna oraz rzeźbę przedstawiającą portret mieszkańca Afryki. Oprócz tego znajdują się tutaj owoce roślin użytkowych: baobabu (kilka dużych okazów), puchowca pięciopręcikowego, czyli drzewa kapokowego [Ceiba pentandra (Stiekm.) Gaertn.] - torebki z nasionami otoczonymi wełnistym puchem zwanym kapokiem, który przez długie lata stosowany był do wyrobu kamizelek ratunkowych, ponieważ nie nasiąka wodą, a także długie, masywne owoce kigelii etiopskiej zwanej drzewem kiełbasianym [Kigelia aethiopum (Fenzl.) Dandy] mającej jadalne nasiona. Stolik ekspozycyjny zawiera schemat przedstawiający układ pięter roślinności w górach Afryki Wschodniej: Mount Kenya, Kilimandżaro i Mount Elgon. Pod szkłem znajdują się okazy zielnikowe roślin górskich, np. Lobelia deckenii (Asch.) Hemsl. - endemit Kilimandżaro występujący w piętrze wrzośców, czy Dendrosenecio keniensis (Baker f.) Mabb. (Senecio brassica R.E.Fr. et Th.Fr. jr.) - endemit Mount Kenya rosnący w piętrze wrzośców i afroalpejskim. 
Urozmaicenie kompozycyjne sali stanowią trzy połączone podesty, na których umieszczone są pnie (zwane kłodzinami, ponieważ nie mają przyrostu wtórnego na grubość), a także owoce i nasiona palm. Rodzina palm (Areceae $=$ Palmae) zawiera najważniejsze gatunki użytkowe obszarów tropikalnych i subtropikalnych dostarczające pokarmu (owoce, sok palmowy), budulca (pnie) i włókna (liście i pochwy liściowe). Trzy wysokie pnie sięgające sufitu to kłodziny palmy Trachycarpus fortunei (Hook.) H. Wendl., występującej w Birmie Północnej i Chinach Środkowych, uprawianej jako ozdobna, rosnącej niegdyś w ogrodowej starej palmiarni (najwyższa z palm zginęła w 1956 roku). Pnie pokryte są grubą warstwą czarnych włókien, którą tworzą pochwy liściowe. Na podestach szczególną uwagę zwraca nasienie lodoicji seszelskiej, czyli palmy seszelskiej (Lodoicea maldivica (J.F.Gmel.) Pers. (Lodoicea sechellarum Labill.) występującej tylko na wyspach Praslin i Curieuse w Archipelagu Seszelskim na Oceanie Indyjskim. Lodoicja wytwarza największe na świecie nasiona dochodzące do 30-50 cm długości i 20-25 kg wagi. W dawnych czasach przenoszone prądami morskimi dopływały do wybrzeży Indii. Nazywano je morskimi orzechami kokosowymi i uważano, że mają czarodziejskie właściwości, stąd też stosowano zwłaszcza w magii miłosnej. Obecnie gatunek objęty jest ścisłą ochroną. Wystawione są dwa okazy: jeden mniejszy, z naturalną łupiną, i drugi znacznie większy, z łupiną częściowo wyszlifowaną (zob. il. IV), co często praktykowano w dawnych muzeach. Jedną z najważniejszych gospodarczo palm jest kokos właściwy, czyli palma kokosowa (Cocos nucifera L.). Pochodzi prawdopodobnie z wysp Pacyfiku, obecnie szeroko uprawiany w całej strefie tropikalnej. Owoc zwany orzechem kokosowym ma gładką okrywę, pod którą występuje warstwa zbudowana z włókien zwana kojrą. Wewnątrz znajduje się otoczone twardą skorupą nasienie właściwe. Bielmo, w postaci białej, mięsistej tkanki, wyściela nasienie od wewnątrz. Wysuszone bielmo, tzw. kopra, jest surowcem do wyrobu oleju kokosowego. Oprócz tego gatunek ten dostarcza włókna, soku palmowego, materiału budulcowego, paszy itd. Wyeksponowany jest cały orzech oraz cztery przekroje. Z innych gatunków można zobaczyć m.in. kolczasty owoc palmy Phytelephas macrocarpa Ruiz \& Pav., pochodzącej z Brazylii i Peru, której nasiona używane są jako substytut kości słoniowej (tzw. roślinna kość słoniowa). Obok znajduje się mała rzeźba głowy wykonana w tym materiale przez mgr. Józefa Wróbla - pracownika Ogrodu. Na trzecim podeście umieszczono owocostany trzech palm: rafii włóknodajnej [Raphia farinifera (Gaertn.) Hyl.] z Afryki tropikalnej i Madagaskaru, której młode liście (skórka) dają włókno, zwane rafią, używaną do wyrobu różnych plecionek oraz w ogrodnictwie, olejowca gwinejskiego (Elaeis guinennsis Jacq.) pochodzącego z Afryki Zachodniej, szeroko uprawianego poza Afryką, należącego obok palmy kokosowej do najważniejszych olejodajnych palm (olej pozyskuje się z nasion), oraz Borassus aethiopum Mart. z Afryki tropikalnej, palmy dostarczającej jadalnych owoców, materiału budowlanego (pnie), surowca do wyrobu mat i plecionek (liście), soku palmowego itp., często rozsiewanej przez słonie, które zjadają chętnie owoce. Przekroje przez kłodziny różnych gatunków pokazane są na wiszącej na ścianie tablicy. W kątach sali stoją pod ścianami cztery pnie palm rosnących niegdyś w palmiarniach (starej działającej w latach 1882-1969 i nowej, w kompleksie szklarni Jubileuszowej wzniesionej w latach 1959-1966). Najbardziej okazały 
jest pień palmy Livistona hasseltii (Hassk.) Wendl. [L. chinensis (Jacq.) R. Br. ex Mart.] pochodzącej z Japonii. Okaz ten, zasadzony w drugiej połowie XIX wieku, był przez długie lata jedną z najwyższych w Europie palm utrzymywanych pod szkłem. W 1953 roku zginął w niszczejącej palmiarni. Inne okazy, które można obejrzeć w sali tropikalnej, to luźno stojący pień pandana (Pandanus sp.) ze szczudłowatymi korzeniami podporowymi, występujący na brzegach morskich i bagnach, m.in. w Azji Południowo-Wschodniej. Jego owoce - pestkowce tworzące duże, szyszkowate owocostany, wiszą na ścianie w siatkach, pomiędzy szafami ze zbiorami Raciborskiego - zostały zebrane przez niego w Ogrodzie Botanicznym w Buitenzorgu. Poniżej stoją grube, zdrewniałe pędy (źdźbła) bambusa. Bambus pospolity (Bambusa vulgaris Schrad.) należący do rodziny traw (Poaceae) - gatunek o nieznanym pochodzeniu, rośnie głównie w strefie międzyzwrotnikowej, uprawiany zwłaszcza w Azji Południowo-Wschodniej. Zdrewniałe pędy mają wszechstronne zastosowanie, m.in. jako materiał budulcowy i stolarski.

\section{Wystawy w piwnicach Collegium Śniadeckiego}

W piwnicach Collegium, posiadających szeroki korytarz prowadzący schodami do sali prelekcyjnej i sali konferencyjnej, wyeksponowano niektóre zbiory muzealne. $\mathrm{Na}$ ścianach korytarza znajdują się cztery wnęki z oszklonymi gablotami. W dwóch urządzono wystawę kilkunastu sztuk modeli kwiatów, szyszek oraz przedrośli skrzypów, wyprodukowanych w latach 1867-1870 przez firmy z Berlina, Pragi, Wiednia i Wrocławia. Przez długie lata używane były jako pomoce dydaktyczne do nauki botaniki na Uniwersytecie Jagiellońskim. Kolejną wnękę poświęcono bambusowi - widać tam zdrewniałe pędy, zasuszone liście i kwiatostany, a także łuskowatą pochwę liściową o pięknej perłowej barwie, ozdobioną rysunkiem piórkiem przedstawiającym kwiaty, autorstwa mgr Elżbiety Nowotarskiej. W ostatniej wnęce wystawiona jest metalowa rzeźba zatytułowana Ocalony świat, wykonana przez krakowskiego metaloplastyka Stefana Luchtera (1913-1993). Na ścianach korytarza oraz w sali prelekcyjnej rozwieszono ponad 50 obrazów roślin i krajobrazów, ofiarowanych przez artystów, którzy mieli wystawy w Muzeum Ogrodu Botanicznego. W sali konferencyjnej zaprezentowano 17 fotografii portretowych przedstawiających zasłużonych botaników Uniwersytetu Jagiellońskiego. Na przeciwległej ścianie wisi duży obraz olejny - portret siostry Mariana Raciborskiego, Marii Wandy Stobieckiej z Raciborskich (1870-1896), namalowany z fotografii w 1898 roku przez Ferdynanda Brylla (1863-1922).

\section{Altana dendrologiczna}

Część zbiorów dendrologicznych wystawiona jest w tzw. altanie dendrologicznej usytuowanej w starej części arboretum, przy zachodnim murze Ogrodu. Murowana altana zaprojektowana w dawnym stylu pochodzi z 2. połowy XX wieku. W 2005 roku urządzono tutaj ekspozycję pni, przekrojów i próbek drewna niektórych gatunków drzew 
i krzewów. Aranżację zaprojektował pracownik Ogrodu mgr Józef Wróbel, który również wyeksponował kilka swoich drewnianych rzeźb.

\section{Wystawy czasowe}

Począwszy od lat 90. XX wieku, organizowane są wystawy czasowe - w ostatnich latach ok. dziesięciu rocznie, głównie malarstwa, fotografii i innych dzieł artystycznych związanych tematycznie z przyrodą, zwłaszcza z botaniką (kwiaty, drzewa, ogrody, krajobrazy itd.) (il. VII, VIII). Autorami wystaw są zarówno artyści profesjonalni, jak i amatorzy. Największą publiczność przyciągają imprezy organizowane w Krakowie od kilkunastu lat: „Noc Muzeów” (w maju) oraz „Dzień Otwarty Muzeów Krakowskich” (jesienią). Muzeum otwierane jest także w czasie „Święta Ogrodów”, zainicjowanego w 2006 roku m.in. przez krakowski Ogród Botaniczny, odbywającego się co roku i trwającego przez dwa tygodnie lub dłużej, w maju i w czerwcu. Festiwal, w którym uczestniczą również inne ogrody, ma na celu popularyzację kultury ogrodowej, idei ochrony przyrody oraz sztuki ukazującej piękno natury. W Ogrodzie, z udziałem Muzeum, organizowane są wtedy wystawy czasowe, koncerty, spotkania poetyckie, wykłady specjalne oraz warsztaty różnego typu.

\section{Działalność naukowa}

Muzeum wraz z Ogrodem Botanicznym wchodzi w skład Instytutu Botaniki UJ i realizuje jego program badawczy i dydaktyczny. Jest ono jedną z nielicznych placówek, w których prowadzone są interdyscyplinarne badania nad historią botaniki (XVI-XX wieku), etnobotaniką oraz relacjami przyroda-nauka-kultura. Powstało tutaj polskie centrum dokumentacji i badań w tych rzadkich specjalnościach. Opublikowano wiele prac naukowych i popularnonaukowych, zorganizowano interdyscyplinarne konferencje, a wyniki badań były referowane w kraju i za granicą. W dniu 23 kwietnia 1983 roku na zebraniu w Muzeum utworzono ogólnopolską Sekcję Historii Botaniki Polskiego Towarzystwa Botanicznego ${ }^{35}$, skupiającą badaczy roślin zainteresowanych przeszłością swojej dyscypliny.

${ }^{35}$ A. Zemanek, Dziesięć lat Sekcji Historii Botaniki Polskiego Towarzystwa Botanicznego [Ten years of the History of Botany Section, Polish Botanical Society], „Kwartalnik Historii Nauki i Techniki” 1994, R. 39, nr 2, s. 159-165. 


\section{Udostępnianie}

Muzeum czynne jest dwa lub trzy dni w tygodniu oraz niedziele (4 godz.) w okresie otwarcia Ogrodu Botanicznego tzn. przez siedem miesięcy w roku - od kwietnia do października. Dla studentów dostępne jest przez cały rok po uprzednim zgłoszeniu.

\section{Ogród Botaniczny Uniwersytetu Jagiellońskiego jako muzeum}

Ogród Botaniczny UJ założony w 1783 roku ma jako całość charakter muzealny. Przetrwał w tym samym miejscu od XVIII wieku, dawniej była to dzielnica Krakowa Wesoła, dzisiaj znajduje się w dzielnicy II - Grzegórzki, z bramą wejściową od ulicy Kopernika 27. Zaaranżowany z dawnego założenia pałacowego o powierzchni ok. 2,4 ha był sukcesywnie powiększany, a w XX wieku objął obszar 9,6 ha ${ }^{36}$. Dzięki temu, że po przyłączaniu nowych terenów nie likwidowano dawnych działów, jest on dzisiaj mozaiką zakątków z różnych epok, co decyduje o jego niepowtarzalnym charakterze. Pierwotnie miał układ tarasowego, geometrycznego parku o kompozycji barokowej typu francuskiego, z prostokątnym stawem pochodzącym z dawnego starorzecza Wisły. Na obszarze przyłączonym w XIX wieku urządzono arboretum w stylu angielskim, o swobodnym układzie grup roślinnych. Poszerzenie terenu w XX wieku pozwoliło na zaaranżowanie nowych działów, we współczesnym stylu krajobrazowym, z rekonstrukcją geometrycznego ogrodu włoskiego, ogródka japońskiego i ogródka wiejskiego. Urozmaiceniem kompozycji są elementy małej architektury: dwie altany, trzy pergole, zbiorniki wodne - oprócz dużego stawu dwa niewielkie stawki, sadzawka z fontanną, kilka basenów z roślinami, a także trzy pomniki.

Nieodłącznym elementem architektury ogrodowej są oranżerie. Krakowski Ogród posiada trzy kompleksy szklarniowe: najstarszy Victoria z lat 1786-1787, którego nazwa pochodzi od wiktorii brazylijskiej (Victoria cruziana A.D. Orb.) rosnącej w pomieszczeniu z basenem. Oranżerie w tym zespole były kilkakrotnie przebudowywane, m.in. w latach 1827, 1856, a szklarnia z basenem rekonstruowana w 1925 i 1995 roku. Znajdujący

${ }^{36}$ A. Piekiełko, Historia Ogrodu Botanicznego Uniwersytetu Jagiellońskiego w Krakowie. Historia Horti Botanici Universitatis Iagiellonicae Cracoviensis. (Sum.: The history of the Jagiellonian University Botanical Garden in Cracow), Warszawa-Kraków 1983; A. Zemanek, „Krakowski ogród wiedzy”- Ogród Botaniczny Uniwersytetu Jagiellońskiego. (Sum.: „Cracow garden of knowledge”Botanic Garden of the Jagiellonian University) [w:] XVII Międzynarodowe Seminarium Sacrum i Przyroda. Ogród Pana. 18th International Seminar Sacrum and Nature. The Garden of the Lord, red. J. Brusiło, Kraków 2010, s. 15-25, k. nlb. 6; A. Zemanek, B. Zemanek, Ogród Botaniczny Uniwersytetu Jagiellońskiego w Krakowie (Sum.: Jagiellonian University Botanic Garden in Cracow), Fot. P. Zechenter, Kraków 1996; B. Zemanek, Ogród Botaniczny Uniwersytetu Jagiellońskiego w Krakowie [Botanic Garden of the Jagiellonian University] [w:] Ogrody botaniczne w Polsce [Botanic gardens in Poland], red. A. Łukasiewicz, J. Puchalski, przy współpracy W. Szumarskiego, W. Gawrysia, Warszawa 2002, s. 23-38; B. Zemanek, Ogród Botaniczny Uniwersytetu Jagiellońskiego 230 lat dla nauki $i$ spoteczeństwa [Botanic Garden of the Jagiellonian University 230 years for science and society], Kraków 2013. 
się w tym kompleksie wysoki zimownik z XIX-wiecznymi palmami jest obecnie w rekonstrukcji. Holenderka - storczykarnia wybudowana w 1954 roku - została zrekonstruowana w 2017 roku. Palmiarnię Jubileuszową wraz z zespołem szklarni tropikalnych wybudowano z okazji 600-lecia Uniwersytetu Jagiellońskiego (1959-1966). Pamięć zasłużonych osób przypominają pomniki: Józefa Warszewicza (1869 rok), Mariana Raciborskiego (1947 rok) i Władysława Szafera (1975 rok).

Żywa kolekcja ma wartość nie tylko przyrodniczą i naukową, ale także historyczną i kulturową, zawiera bowiem wiele starych roślin, funkcjonujących w kulturze, przedstawianych w poezji i malarstwie, np. ok. 230-letni dąb szypułkowy (Quercus robur L.), zwany dębem Jagiellońskim, czy dwa ponaddwustuletnie okazy derenia właściwego (Cornus mas L.), tzw. derenie Śniadeckiego posadzone ok. 1790 roku - jak głosi tradycja ręką założyciela Obserwatorium Astronomicznego. W dniu 28 maja 1976 roku Ogród Botaniczny UJ wpisany został do rejestru zabytków, ponieważ ,posiada wybitne walory przyrodnicze (...) oraz wartość historyczną. Jest placówką naukową i dydaktyczną. Jako taki zasługuje w pełni na ochronę prawa" ${ }^{\text {"37 }}$. Ogród, czyli „żywe muzeum”, tworzy niepowtarzalną całość z kolekcjami tradycyjnych okazów muzealnych. Prezentują one różnorodność i piękno roślinnego świata oraz wysiłki ludzi, którzy poświęcili życie badaniom ich w różnych regionach Ziemi.

\section{Bibliografia}

\section{Wybrane materiaty archiwalne}

Muzeum Ogrodu Botanicznego, Instytut Botaniki, Wydział Biologii, Uniwersytet Jagielloński Teczki archiwalne: B (Botanicy) - B-109; Muzeum Ogr. Bot. UJ - sygnatury od Muz. 1 do Muz. 32; OB - sygnatury OB-43, OB-93.

Archiwalne materiały biograficzne można znaleźć w cytowanych poniżej opracowaniach drukowanych.

\section{Opracowania}

Bobbé I., Kilimandżaro-75, „WTK” 33(1129), 15 VIII 1976, ss. 2 nlb. [Luźne kartki w zbiorach Muzeum Ogrodu Botanicznego UJ, sygn. B-109].

Botanic gardens. A living history, red. N.K. Monem, London 2007.

Köhler P., Dziewiętnastowieczne pomoce naukowe w zbiorach Muzeum Ogrodu Botanicznego Uniwersytetu Jagiellon'skiego. The $19^{\text {th }}$ century educational appliances in the Museum of the Jagiellonian University Botanic Garden, „Wiadomości Botaniczne” 1991, vol. 35, nr 3/4, s. 96-99.

Köhler P., Najstarsze zbiory Muzeum Ogrodu Botanicznego Uniwersytetu Jagiellońskiego. The oldest collections in the Museum of the Jagiellonian University Botanic Garden, „Wiadomości Botaniczne" 1991, vol. 35, nr 1, s. 74-78.

\footnotetext{
${ }^{37}$ Kopia dokumentu w Muzeum OBUJ.
} 
Köhler P., Zbiory archiwalne Muzeum Botanicznego i Pracowni Historii Botaniki im. J. Dyakowskiej Ogrodu Botanicznego Uniwersytetu Jagiellońskiego, „Krakowski Rocznik Archiwalny” 1999, t. 5, s. 190-197.

Köhler P.S., Zbiory dendrologiczne dawnego Krakowskiego Muzeum Techniczno-Przemysłowego w Muzeum Ogrodu Botanicznego Uniwersytetu Jagiellońskiego. The dendrological collection of the former Cracow Technical-Industrial Museum in the Museum of the Jagiellonian University Botanic Garden, „Wiadomości Botaniczne” 1990, vol. 34, nr 4, s. 70-72.

Köhler P., Zemanek A., Dziesięciolecie otwarcia Muzeum Ogrodu Botanicznego Uniwersytetu Jagiellońskiego w Krakowie (1983-1993). Ten years of the Museum of the Jagiellonian University Botanic Garden, Cracow, Poland (1983-1993), „Wiadomości Botaniczne” 1994, vol. 38 , nr 3/4, s. 170-174.

Köhler P.S., Zemanek A., Zbiory Mariana Raciborskiego w Muzeum Ogrodu Botanicznego Uniwersytetu Jagiellońskiego. The Marian Raciborski collection in the Museum of the Jagiellonian University Botanic Garden, „Zeszyty Naukowe UJ. Prace Botaniczne” 1989, z. 18, s. $135-148$.

Köhler P., Zemanek A., Zespół pałacowy Collegium Śniadeckiego UJ. Zakończenie rewaloryzacji [The Śniadecki Collegium JU, former palace The end of restoration], „Alma Mater”, czerwiec-wrzesień 2015, nr 175-176, s. 54-57.

Kornaś J., A new species of Athyrium (Aspleniaceae) from Zambia, „Kew Bulletin” 1978, vol. 33, nr 1, s. 99-101.

Kornaś J., Life-forms and seasonal patterns in the pteridophytes in Zambia, „Acta Societatis Botanicorum Poloniae" 1977, vol. 46, nr 4, s. 669-690.

Mägdefrau K., Historia botaniki. Życie i dokonania wielkich badaczy, przeł. M. Mularczyk, Wrocław 2004.

Morton A.G., History of botanical science. An account of the development of botany from ancient times to the present day, London, New York, Toronto, Sydney, San Francisco 1981.

Oldfield S., Botanic garden Modern-day arks, London, Cape Town, Sydney, Auckland 2010.

Pawęski F., Muzealnictwo botaniczne, praca doktorska, promotor: prof. dr Jakub Mowszowicz, b.r. Egzemplarz w Bibliotece Instytutu Botaniki im. W. Szafera PAN, sygn. III 3155.

Piekiełko A., Dwa osiemnastowieczne zielniki ze zbiorów Instytutu Botaniki Uniwersytetu Jagiellońskiego. (Sum.: Two 18-th century herbaria from the collection of the Institute of Botany of the Jagiellonian University), Wrocław, Warszawa, Kraków, Gdańsk 1981.

Piekiełko A., Historia Ogrodu Botanicznego Uniwersytetu Jagiellońskiego w Krakowie. Historia Horti Botanici Universitatis Iagiellonicae Cracoviensis. (Sum.: The history of the Jagiellonian University Botanical Garden in Cracow), Warszawa, Kraków 1983.

Piekiełko-Zemanek A., Kalendarium życia Mariana Raciborskiego. A calendar of life of Marian Raciborski [w:] Marian Raciborski. Studia nad życiem i działalnościa naukowa. De Mariani Raciborski vita et scriptis, red. J. Kornaś, Warszawa, Kraków 1986, s. 9-43, tabl. k. 1 nlb.

Piekiełko-Zemanek A., Zbiory muzealne Ogrodu Botanicznego Uniwersytetu Jagiellońskiego w Krakowie. Museum assemblage of Botanical Garden of the Jagiellonian University in Kraków, „Wiadomości Botaniczne” 1985, t. 29, z. 1, s. 59-68.

Raciborski M., Die Pteridophyten der Flora von Buitenzorg, Leiden 1898.

Świecimski J., Zemanek A., Muzeum Ogrodu Botanicznego Instytutu Botaniki Uniwersytetu Jagiellońskiego w Krakowie. (Sum.: Botanical Garden Museum in the Institute of Botany, the Jagiellonian University in Cracow), „Zeszyty Naukowe UJ. Opuscula Musealia” 1992, z. 6, s. 7-19.

Warchałowska-Śliwa E., Jerzy Świecimski (1927-2012), prof. dr hab. [w:] Ćwierćwiecze Instytutu Systematyki i Ewolucji Zwierzat Polskiej Akademii Nauk w Krakowie. 150 lat tradycji badawczych i muzealnych, red. E. Warchałowska-Śliwa, Kraków 2014, s. 99. 
Zemanek A., Dziesięć lat Sekcji Historii Botaniki Polskiego Towarzystwa Botanicznego [Ten years of the History of Botany Section, Polish Botanical Society], „Kwartalnik Historii Nauki i Techniki" 1994, r. 39, nr 2, s. 159-165.

Zemanek A., Historia botaniki [History of botany] [w:] Dzieje nauki. Nauki ściste i przyrodnicze [History of science. Exact sciences and natural sciences], red. M. Siwiec, Warszawa, Bielsko-Biała 2011, s. 390-455.

Zemanek A., Koleje życia Józefa Rostafińskiego [w:] Józef Rostafiński botanik i humanista. (Sum.: Józef Rostafinski - a botanist and humanist), red. A. Zemanek, Kraków 2000, s. 19-106, ss. 30 nlb. (ilustracje).

Zemanek A., ,Krakowski ogród wiedzy” - Ogród Botaniczny Uniwersytetu Jagiellońskiego. (Sum.: „Cracow garden of knowledge” - Botanic Garden of the Jagiellonian University) [w:] XVII Międzynarodowe Seminarium Sacrum i Przyroda. Ogród Pana. 18th International Seminar Sacrum and Nature. The Garden of the Lord, red. J. Brusiło, Kraków 2010, s. 15-25, k. nlb. 6 .

Zemanek A., Łowca roślin Józef Warszewicz (1812-1866) - w 200-lecie urodzin [Plant hunter Józef Warszewicz (1812-1866) - on the 200th anniversary of his birth], „Alma Mater”, grudzień-styczeń 2012-2013, nr 152-153, s. 43-46.

Zemanek A., Muzeum Ogrodu Botanicznego UJ [Museum of the Botanic Garden JU], „Alma Mater" 2013, nr specjalny, wrzesień, nr 158, s. 111-114.

Zemanek A., Muzeum Ogrodu Botanicznego Uniwersytetu Jagiellońskiego [Museum of the Botanic Garden, Jagiellonian University] [w:] Muzea uczelniane Katalog [Association of University Museums Catalogue] red. K. Kowalski, M. Grassman, M. Bukowski, J. Ślaga, M. Piszczatowska, M. Przybyszewska (redaktor prowadzący), Warszawa 2017, s. 126-131.

Zemanek A., Sto lat Instytutu Botaniki Uniwersytetu Jagiellońskiego (1913-2013). (Sum.: 100 years of Institute of Botany of the Jagiellonian University), Kraków 2013.

Zemanek A., Klepacki P., Muzeum Ogrodu Botanicznego Uniwersytetu Jagiellońskiego w Krakowie [Museum of the Botanic Garden, Jagiellonian University in Cracow] [w:] Muzealnictwo przyrodnicze w Polsce [Museology of natural history in Poland], red. D.J. Gwiazdowicz, Gołuchów 2017, s. 105-113.

Zemanek A., Zemanek B., Ogród Botaniczny Uniwersytetu Jagiellońskiego w Krakowie (Sum.: Jagiellonian University Botanic Garden in Cracow), Kraków 1996.

Zemanek B., Ogród Botaniczny Uniwersytetu Jagiellońskiego 230 lat dla nauki i społeczeństwa [Botanic Garden of the Jagiellonian University 230 years for science and society], Kraków 2013.

Zemanek B., Ogród Botaniczny Uniwersytetu Jagiellońskiego w Krakowie [Botanic Garden of the Jagiellonian University in Cracow] [w:] Ogrody botaniczne w Polsce [Botanic gardens in Poland], red. A. Łukasiewicz, J. Puchalski, przy współpracy W. Szumarskiego, W. Gawrysia, Warszawa 2002, s. 23-38.

Ziobrowski S., Rośliny nazwiskiem J. Warszewicza oznaczone, „Ogrodnictwo” 1927, r. 23, z. 1, s. 14-25. 


\section{Alicja Zemanek}

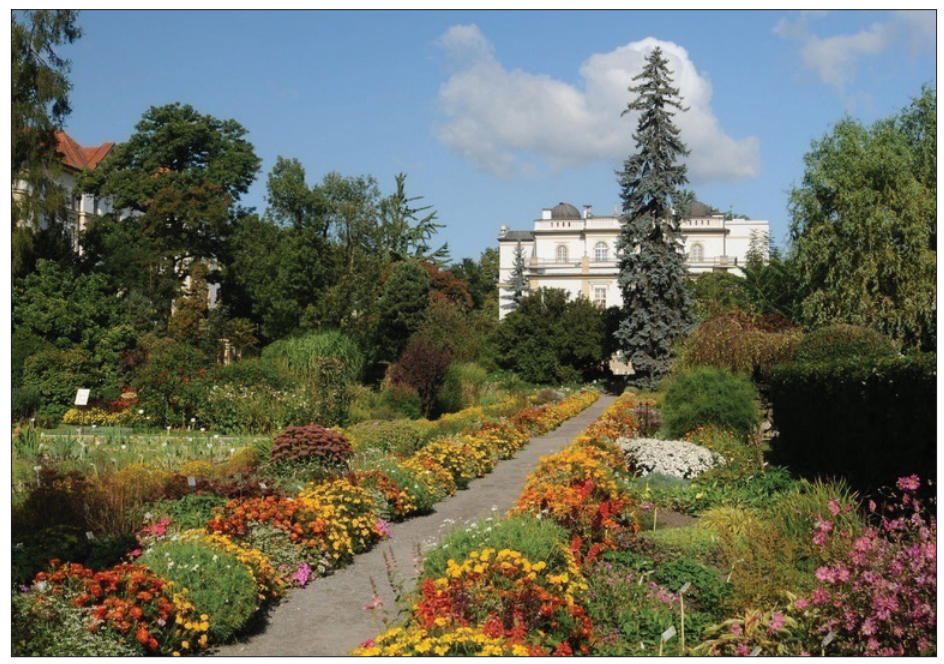

Il. I. Główna aleja w Ogrodzie Botanicznym - tzw. wstążka krakowska. W głębi budynek Collegium Śniadeckiego UJ. Fot. A. Mróz. Ze zbiorów Muzeum Ogrodu Botanicznego UJ

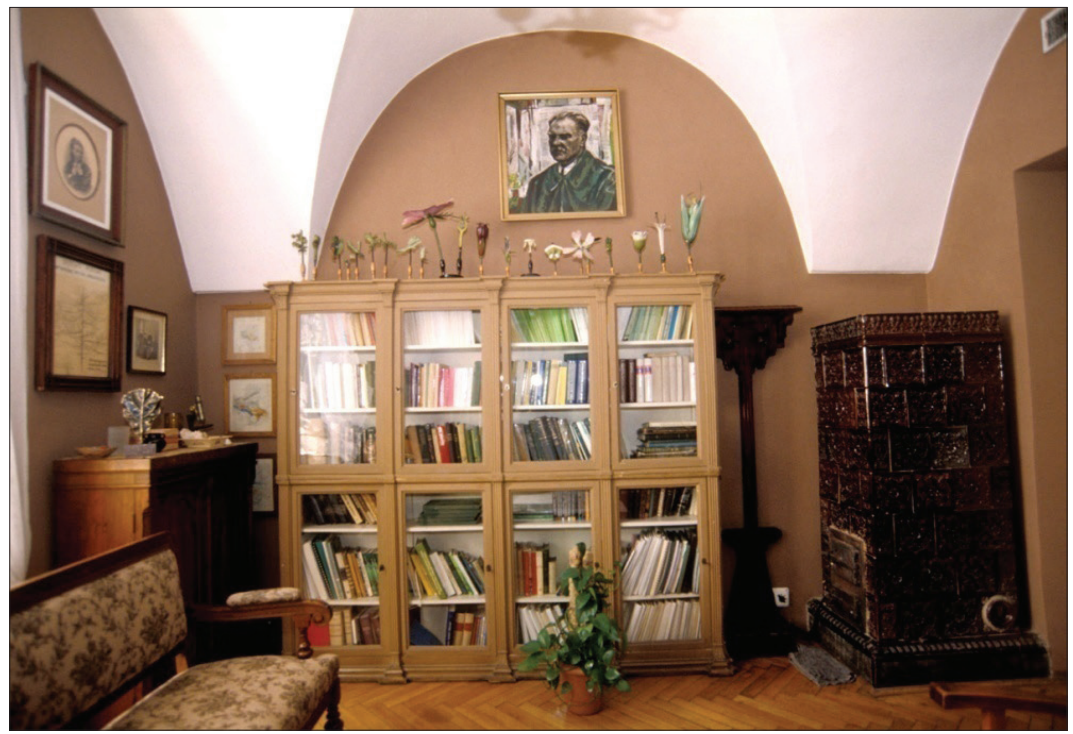

Il. II. Pracownia z zabytkowymi meblami i materiałami do historii botaniki. Fot. A. Mróz. Ze zbiorów Muzeum Ogrodu Botanicznego UJ 


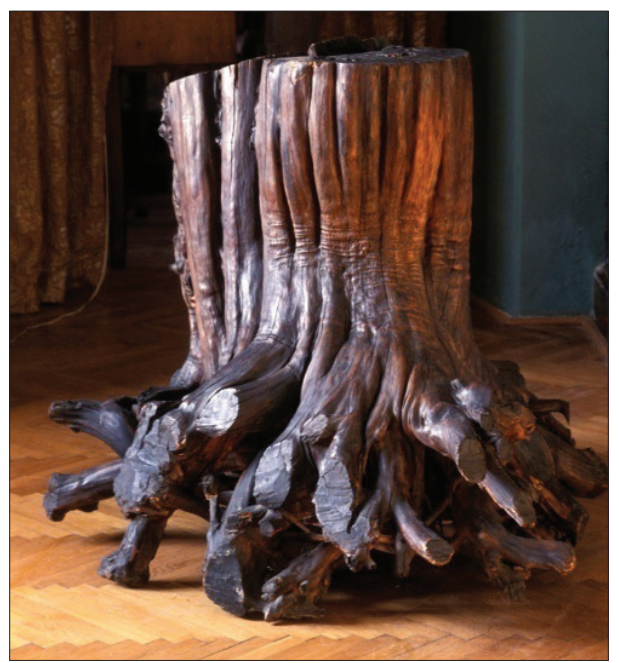

Il. III. Pień ok. 500-letniego cisa pospolitego (Taxus baccata L.). Ze zbiorów Muzeum Ogrodu Botanicznego UJ

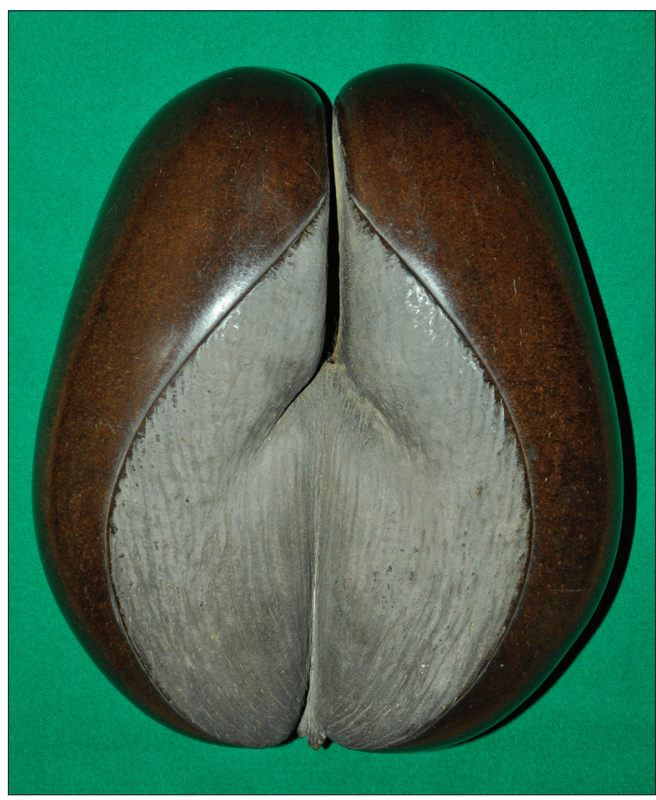

Il. IV. Nasienie lodoicji seszelskiej zwanej palmą seszelską [Lodoicea maldivica (J.F. Gmelin) Pers.], wymiary $43 \times 36 \times 18 \mathrm{~cm}$. Okaz z częściowo oszlifowaną łupiną, XIX wiek, wyeksponowany na podeście z palmami. Fot. B. Sikora-Majewska. Ze zbiorów Muzeum Ogrodu Botanicznego UJ 


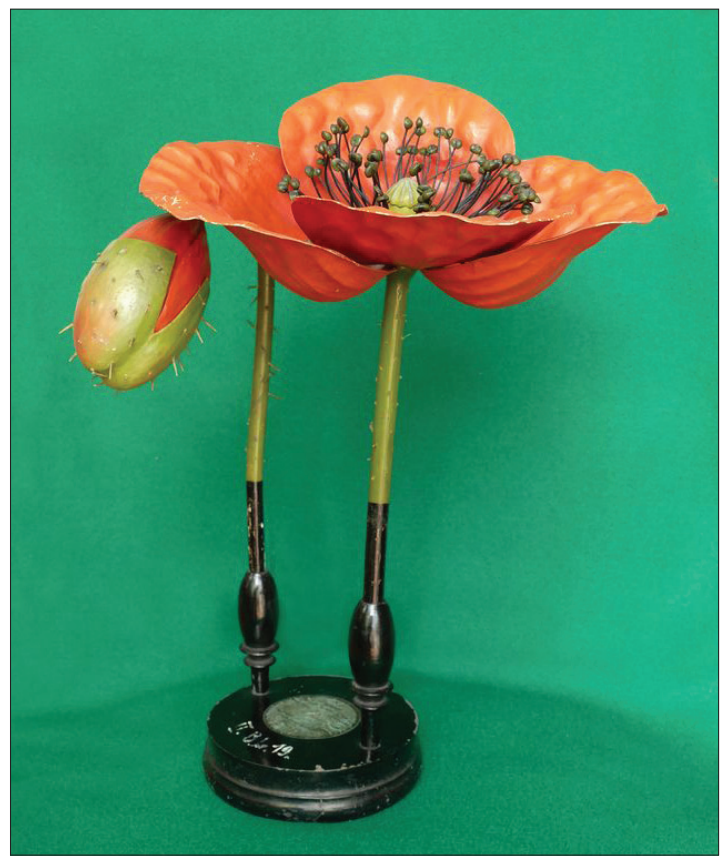

Il. V. Model kwiatu maku polnego (Papaver rhoeas L.). Firma A. Pichlers Witwe et Sohn, Wiedeń, ok. 1867-1870. Ze zbiorów Muzeum Ogrodu Botanicznego UJ

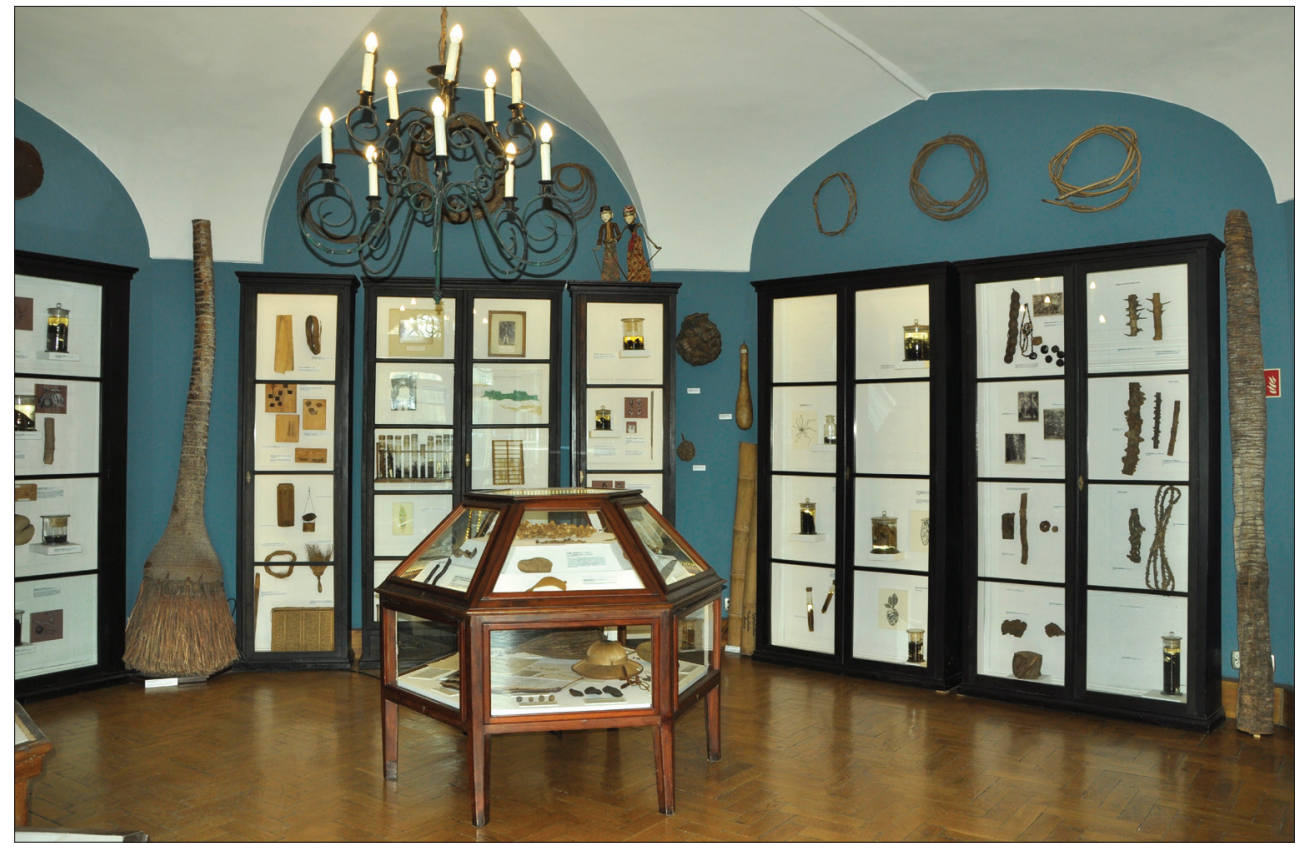

Il. VI. Sala „Botanika tropikalna w Krakowie”. Fot. B. Sikora-Majewska. Ze zbiorów Muzeum Ogrodu Botanicznego UJ 


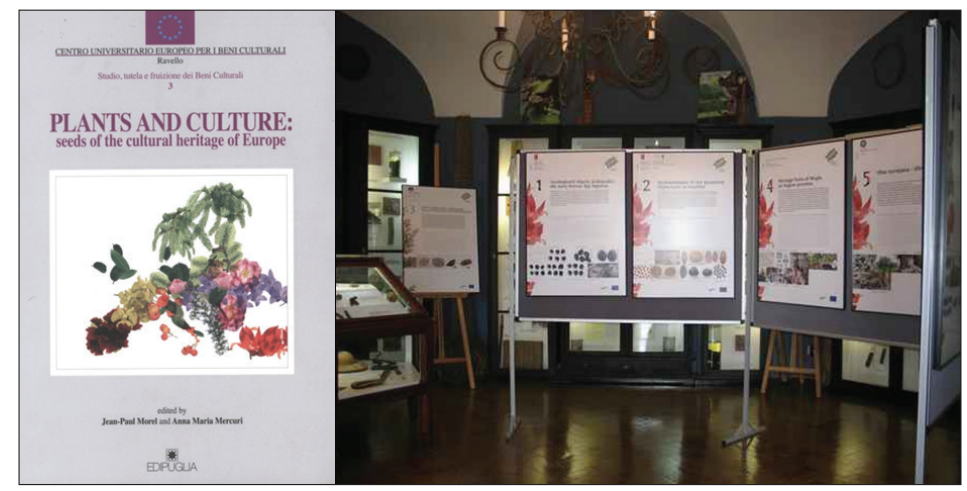

Il. VII. Międzynarodowa wystawa „Plants and culture”, 2008. Fot. A. Mróz. Ze zbiorów Muzeum Ogrodu Botanicznego UJ

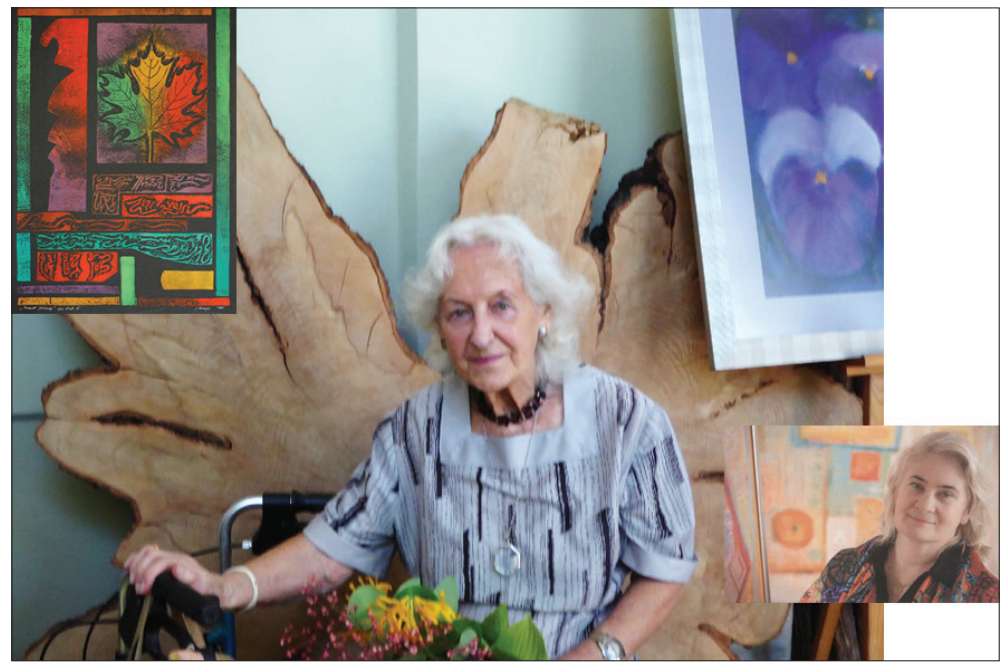

Il. VIII. Prof. Janina Kraupe w czasie wernisażu swojego malarstwa z cyklu „Uczeń i mistrz” (wystawa wraz Martą Kulą-Ulatowską), 28 maja 2015 roku. Fot. M. Lankosz-Mróz. Ze zbiorów Muzeum Ogrodu Botanicznego UJ 